\title{
SHOULD GOOGLE'S SECRET SAUCE BE ORGANIC?
}

\author{
FLORIAN WAGNER-VON PAPP*
}

This commentary discusses the European antitrust investigation into Google and the international implications of the case. It focuses on Google's alleged dominance and the allegations concerning Google's self-preferencing of its Google Shopping results on general web search result pages, which form the subject matter of the Statement of Objections that the European Commission ('Commission') sent on 15 April 2015. As a threshold matter, the Commission's international jurisdiction to prescribe is found to be unproblematic. However, the tendency towards over-enforcement resulting from the cumulation of national and supranational investigations by competition authorities worldwide counsels caution in borderline cases. And, as the assessment of the merits of the case shows, Google is indeed a borderline case. While it seems possible to construct a story of dominance and consumer harm, this paper doubts Google's ability to act to an appreciable extent independently of its competitors and customers. Ultimately, this is an empirical question and the Commission may have sufficient evidence at its disposal. However, the publicly available evidence does not seem to support a finding of dominance, despite Google's high share of user searches. With regard to a finding of abuse, classifying Google's self-preferential treatment as an abuse would require changing the goalposts: one would have to accept that instead of a constructive refusal to deal, it is already abusive if services are not provided to third parties on identical conditions, or that instead of requiring coercion of consumers to acquire a tied product or service, it is already abusive if consumers are merely nudged to preferring the vertically integrated firm's products. These changes would amount to a paradigm change. Traditionally, competition is meant to force producers to be responsive to consumer preferences. Consumer choices are taken to reveal their preferences unless coercion can be shown. Allowing intervention already below the threshold of coercion, when consumers are merely nudged to make particular choices, risks substituting the competition authority's assessment for consumer preferences.

\section{CONTENTS}

I Introduction

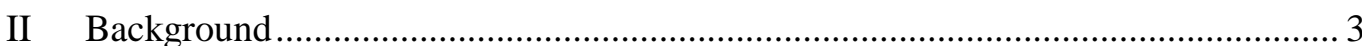

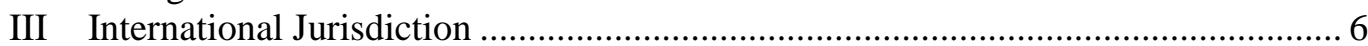

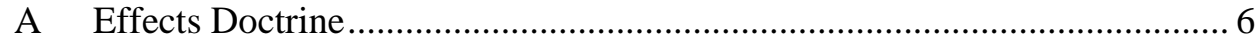

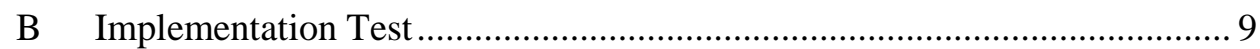

C Nationality Principle...................................................................... 10

D Limits to the Exercise of International Jurisdiction.................................... 11

E Bias towards Over-Enforcement because of Multiple Enforcement .......... 13

IV The Merits of the Case........................................................................................ 16

A Market Definition and Shares.................................................................. 16

* Reader in Law (Associate Professor), University College London, Faculty of Laws, United Kingdom. I would like to thank the three anonymous referees for very helpful comments, the Editors for their very diligent and helpful editing and Thomas Graf, John Kallaugher, Ioannis Lianos, Fabien Curto Millet, Paul Shaw and Danny Sokol, as well as the participants at the Antitrust Enforcement Symposium 2015, Pembroke College, Oxford, for helpful comments and lively discussions on many of the issues touched upon in this paper. As Eric Goldman has pointed out, one should pay close attention to the authors' affiliations when reading Google-related literature: Eric Goldman, 'Revisiting Search Engine Bias’ (2011) 38 William Mitchell Law Review 96, 107-9. While I am not involved in the Google case on either side, given Microsoft's prominent role in the Google case I should mention in the spirit of full disclosure that I was once involved in an unrelated private action brought by Canadian plaintiffs against Microsoft. 
1 Preliminary Observations on Search Shares

in a Two-Sided Business Model..................................................... 16

2 Searching for Competitive Constraints on Google.......................... 20

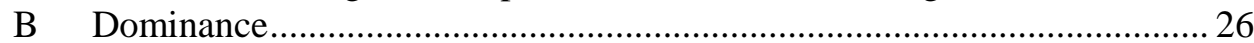

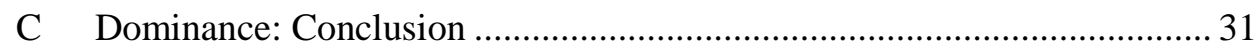

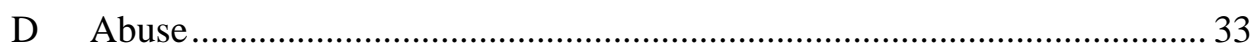

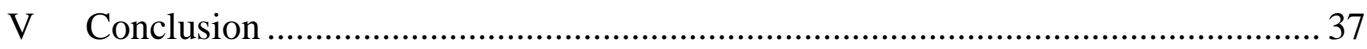

\section{INTRODUCTION}

This commentary discusses the European antitrust investigation into Google and the international implications of the case. It focuses on the allegations concerning Google's self-preferencing of its Google Shopping results on general web search result pages, which form the subject matter of the Statement of Objections that the European Commission ('Commission') sent on 15 April 2015. ${ }^{1}$ Part II outlines the development of the Google case ${ }^{2}$ in Europe and may be safely skipped by anyone who has been following the case in the newspapers (or on Google News). ${ }^{3}$

Part III addresses the international aspects of the case, specifically the European Union's international jurisdiction and the international implications of the case. I argue that the Commission has international jurisdiction to prescribe Google's conduct under an effects and an implementation test, and that public international law principles, such as the principle of noninterference, comity principles or the bilateral United States-European Union agreements, do not prevent the Commission from pursuing the case. Nor is the Commission's antitrust scrutiny of Google driven by political or protectionist motives. However, I argue that the inherent danger of over-enforcement created by

1 This commentary does not discuss the following: (1) any of the allegations concerning matters other than competition law (eg privacy, data protection or tax issues); (2) any of the three allegations of competition law infringements other than self-preferencing that were initially considered in the same investigation (scraping, exclusivity and ad campaign portability), but were not included in the Statement of Objections (see below Part II. On scraping and ad campaign portability, see, eg, Renato Nazzini, 'Google and the (Ever-Stretching) Boundaries of Article 102 TFUE [sic]' (2015) 6 Journal of European Competition Law \& Practice 301, 310-13); (3) the no-poaching agreement between various tech firms including Google (see United States of America v Adobe Systems Inc (DC, No 10-CV-1629, 18 March 2011); Re High-Tech Employee Antitrust Litigation (ND Cal, No 11-CV-02509-LHK, 2 September 2015). The latter was an order granting final approval of class action settlement); (4) the Google/Apple interlocking directorship (see, eg, Jon M Garon, 'Searching Inside Google: Cases, Controversies and the Future of the World's Most Provocative Company’ (2010) 30 Loyola of Los Angeles Entertainment Law Review 429, 439-44); and (5) the European Commission's ('Commission') investigation into Android, which was opened on the same day the Statement of Objections was announced (15 April 2015) (see, eg, European Commission, 'Antitrust: Commission Opens Formal Investigation against Google in relation to Android Mobile Operating System' (Fact Sheet, MEMO/15/4782, 15 April 2015) <http://perma.cc/GAJ9-KWSW> ('EU Commission Investigation into Android')).

2 Google (Case No COMP/AT.39740).

3 For a detailed summary, see Brad Stone and Vernon Silver, 'Google’s \$6 Billion Miscalculation on the EU: Why the Search Leader's Antitrust Deal Fell Apart', Bloomberg Business (online), 6 August $2015<$ http://perma.cc/EFM5-NMCL>; Andrea Renda, 'Searching for Harm or Harming Search? A Look at the European Commission's Antitrust Investigation against Google' (Report No 118, Centre for European Policy Studies, September 2015) <https://perma.cc/ZK8J-AHPZ?type=source>. 
multiple enforcers - that each applies their antitrust laws to more or less the same conduct - should make enforcers cautious in borderline cases.

In order to find out whether Google is such a borderline case in which enforcers should exercise self-restraint, Part IV discusses the substance of the Google case. I explain why I find it prima facie improbable both that Google has a dominant position and that the conduct is abusive, but I also outline what empirical evidence would be needed to show dominance and abuse. Part V concludes.

\section{BACKGROUND}

The Commission opened an antitrust investigation into Google on 30 November 2010.4

On 21 May 2012, then Vice-President and Competition Commissioner Joaquín Almunia outlined four competition concerns in a speech and in a letter to Google. ${ }^{5}$ First, Google was said to display so-called 'Google Specialised Results Links' to its own specialised, or 'vertical', ${ }^{6}$ search services in the search results of its general web search engine more prominently than their organic search algorithm would otherwise allow, thereby demoting links to vertical search services of its competitors ('self-preferential treatment'). Specialised, or vertical, search sites are search engines that let users search specifically in a particular domain, for example for restaurants, products, news, hotels or flights. Examples for specialised search sites are Google Shopping and its competitors Amazon, eBay or Foundem; Google Local and its competitor Yelp; and Google Travel and its competitors Expedia, Kayak, Opodo and TripAdvisor. Vertical search services are to be distinguished from general, or 'horizontal', search engines such as Bing, DuckDuckGo, Google or Yahoo!.

Secondly, the Commission was concerned that Google copied content such as user reviews from its competitors' vertical search engines and used this content without permission in its own vertical services ('scraping').

Thirdly, Google was accused of demanding de facto exclusivity where websites sought to offer Google search advertisements ('exclusivity').

Fourthly, the Commission investigated restrictions Google placed on the portability of ad campaigns developed for its platform AdWords to competing platforms for search advertising ('ad campaign portability').

4 European Commission, 'Antitrust: Commission Probes Allegations of Antitrust Violations by Google' (Press Release, IP/10/1624, 30 November 2010) <https://perma.cc/ ZK8J-AHPZ?type=source $>$. Initially, these were: Foundem $v$ Google (Case No COMP/C-3/39.740); 1plus v Google (Case No COMP/C-3/39.775); Ciao v Google (Case No COMP/C-3/39.768). In 2013, the cases were merged into: Google (Case No COMP/AT.39740).

5 Joaquín Almunia, 'Statement of VP Almunia on the Google Antitrust Investigation' (Press Release, SPEECH/12/372, 21 May 2012) <http://perma.cc/E8FK-7BBQ>.

6 Michael Salinger and Robert Levinson have correctly pointed out that the terminology 'vertical' is misleading (certainly for antitrust lawyers and economists) and that what is meant is specialised (as opposed to 'general') search. See Michael A Salinger and Robert J Levinson, 'Economics and the FTC’s Google Investigation' (2015) 46 Review of Industrial Organization 25, 27. 
In the same speech, Vice-President Almunia outlined his preference for a quick resolution by way of voluntary commitments under art 9 of Regulation 1/2003 (vulgo: a 'settlement'). ${ }^{7}$

In March 2013, the Commission formally informed Google of its preliminary assessment that the four concerns outlined above constituted abuses of a dominant position. ${ }^{8}$ Google proposed a first set of commitments, offering, among other things: (1) to label Google Specialised Result Links and to separate them clearly from the 'Generic Search Results' determined by the general search algorithm; (2) to display search results linking to three of its competitors' vertical search results prominently; (3) to allow its competitors to opt out selectively of the use of their content in Google's vertical search services without being unduly affected in the ranking in the 'Generic Search Results'; and (4) to remove contractual obligations resulting in exclusivity or difficulties in porting ad campaigns across platforms. ${ }^{9}$ The Commission market-tested these commitments

7 Almunia, 'Statement of VP Almunia on the Google Antitrust Investigation', above n 5. In European Union terminology, 'settlements' (of cartel cases, in which parties admit participation in an infringement and liability in return for a 10 per cent reduction of the fine) are distinct from 'commitments' (for non-cartel cases, where no infringement is admitted and the remedies are negotiated). Contrast art 9 of Regulation (EC) No 1/2003 with art 10a of Regulation (EC) No 773/2004, as amended by Regulation (EC) No 622/2008: Council Regulation (EC) No 1/2003 of 16 December 2002 on the Implementation of the Rules on Competition Laid Down in Articles 81 and 82 of the Treaty [2003] OJ L 1/1, art 9; Commission Regulation (EC) No 773/2004 of 7 April 2004 relating to the Conduct of Proceedings by the Commission pursuant to Articles 81 and 82 of the EC Treaty [2004] OJ L 123/18; Commission Regulation (EC) No 622/2008 of 30 June 2008 Amending Regulation (EC) No 773/2004, as regards the Conduct of Settlement Procedures in Cartel Cases [2008] OJ L 171/3. See also Commission Notice on the Conduct of Settlement Procedures in View of the Adoption of Decisions pursuant to Article 7 and Article 23 of Council Regulation (EC) No 1/2003 in Cartel Cases [2008] OJ C 167/1. For a discussion generally on the advantages and disadvantages of the commitment procedure, see, eg, Niamh Dunne, 'Commitment Decisions in EU Competition Law' (2014) 10 Journal of Competition Law \& Economics 399; Florian Wagner-von Papp, 'Best and Even Better Practices in Commitment Procedures after Alrosa: The Dangers of Abandoning the "Struggle for Competition Law", (2012) 49 Common Market Law Review 929; Heike Schweitzer, 'Commitment Decisions under Article 9 of Regulation 1/2003: The Developing EC Practice and Case Law' in Claus-Dieter Ehlermann and Mel Marquis (eds), European Competition Law Annual 2008: Antitrust Settlements under EC Competition Law (Hart, 2010) 547; Wouter PJ Wils, 'The Use of Settlements in Public Antitrust Enforcement: Objectives and Principles' (2008) 31 World Competition 335; Wouter PJ Wils, 'Settlements of EU Antitrust Investigations: Commitment Decisions under Article 9 of Regulation 1/2003' (2006) 29 World Competition 345. For a comparison to United States practice, see George Stephanov Georgiev, 'Contagious Efficiency: The Growing Reliance on US-Style Antitrust Settlements in EU Law' [2007] Utah Law Review 971. For an examination into whether commitment decisions became more prevalent under Vice-President Joaquín Almunia (as is often claimed), see Wouter PJ Wils, 'Ten Years of Commitment Decisions under Article 9 of Regulation 1/2003: Too Much of a Good Thing?' (Paper presented at the New Frontiers of Antitrust Concurrences Journal $6^{\text {th }}$ International Conference, Paris, 15 June 2015).

8 European Commission, 'Antitrust: Commission Seeks Feedback on Commitments Offered by Google to Address Competition Concerns' (Press Release, IP/13/371, 25 April 2013) <http://perma.cc/4YW9-2NSA> ('Press Release IP/13/371'). The prohibition of abuses of dominant positions is provided for in: Consolidated Version of the Treaty on the Functioning of the European Union [2012] OJ C 326/47, art 102 ('Consolidated TFEU').

9 Google Inc, 'Commitments in Case COMP/C-3/39.740 — Foundem and Others', Commitments in Foundem $v$ Google, No 39740-8608-5, 3 April 2013 <http://perma.cc/L7S8-B6R7>; Press Release IP/13/371, above n 8; European Commission, 'Commission Seeks Feedback on Commitments Offered by Google to Address Competition Concerns - Questions and Answers' (Memorandum, MEMO/13/383, 25 April 2013) $<$ http://perma.cc/F67N-J69M> ('MEMO 13/383'). 
in April 2013.10 The feedback to this market test was, in the words of Vice-President Almunia, 'very negative'; the 'strongest critical comments' referred to the first concern, that is, self-preferential treatment of Google Specialised Results Links. ${ }^{11}$

By October 2013, Google had offered to improve its commitments, among other things, by making their competitors' links more visible and by appointing an independent monitoring trustee. ${ }^{12}$ Again, 'interested parties' raised concerns that these commitments were insufficient to address the competition issues.

In February 2014, Vice-President Almunia announced that Google had submitted a third proposal for a set of commitments, now promising to display three of their competitors' vertical search results comparably prominently as the results from its own existing and future vertical search services. ${ }^{13}$ Comparability meant in particular that, where Google used pictures to display its own results, it would also use pictures for its competitors' results; for mobile displays, similar commitments were offered, albeit with a concession to the constraints of smaller screens. The inclusion into one of the prominently displayed spots would be free of charge where inclusion in Google's vertical search services are available free of charge, and would be auctioned off where Google charges for the inclusion in the vertical search results.

Vice-President Almunia was confident that this third set of proposed commitments would put an end to the Google saga. ${ }^{14}$ However, various interested parties who considered the proposed commitments inadequate to address the competition concerns lobbied hard against the adoption of a commitment decision on this basis. Given the bad publicity Google had in unrelated matters during that time - in particular, the Google Street View wi-fi data sniffing and the US National Security Agency scandals, other privacy and data protection concerns, as well as tax issues - it became politically expedient for politicians to cast themselves as strong opponents of Google. ${ }^{15}$ In this

10 See Press Release IP/13/371, above n 8; MEMO 13/383, above n 9; Communication from the Commission Published pursuant to Article 27(4) of Council Regulation (EC) No 1/2003 in Case AT.39740 — Google [2013] OJ C 120/22.

11 Joaquín Alumnia, 'The Google Antitrust Case: What Is at Stake?' (Speech delivered at the European Parliament Hearing, European Commission, Brussels, 1 October 2013) 3-4 $<$ http://perma.cc/7MRU-Y24U>.

12 Ibid.

13 Joaquín Almunia, 'Statement on the Google Investigation' (Press Conference, SPEECH/14/93, 5 February 2014) <http://perma.cc/F5DZ-ABP2>. See also European Commission, 'Antitrust: Commission Obtains from Google Comparable Display of Specialised Search Rivals' (Press Release, IP/14/116, 5 February 2014) <http://perma.cc/BH43-XBQY>; European Commission, 'Antitrust: Commission Obtains from Google Comparable Display of Specialised Search Rivals - Frequently Asked Questions’ (Memorandum, MEMO/14/87, 5 February 2014) <http://perma.cc/QP3H-SSP4>.

14 Vice-President Almunia said, 'I believe that Google's new proposals are capable of addressing the competition concerns I set out to them': Almunia, 'Statement on the Google Investigation', above n 13. See also Christopher Werth, EU's New Competition Chief Could Shake Up Google Antitrust Case (30 October 2014) National Public Radio $<$ http://perma.cc/3CDH-3C9E $>$. Indeed, publications at the time took the commitment decision to be a done deal: Joyce Verhaert, 'The Challenges Involved with the Application of Article 102 TFEU to the New Economy: A Case Study of Google' (2014) 35 European Competition Law Review 265, 265-6.

15 See, eg, Torsten Körber, 'Common Errors regarding Search Engine Regulation - And How to Avoid Them’ (2015) 36 European Competition Law Review 239, 239-40. 
climate, Vice-President Almunia did not manage to finalise the Google commitments during his term as Commissioner.

In November 2014, Margrethe Vestager took over as the new Competition Commissioner. In her confirmation hearings, members of the European Parliament repeatedly asked her about her stance on Google.

Later in the same month, the European Parliament passed a non-binding resolution, in which it called on the Commission 'to enforce EU competition rules decisively' and 'to consider proposals aimed at unbundling search engines from other commercial services', and noted that 'indexation, evaluation, presentation and ranking by search engines must be unbiased and transparent' ${ }^{16}$

On 15 April 2015, the Commission sent a Statement of Objections to Google, focusing - at least for the time being - on the first of the four concerns, the 'self-preferencing', limited to comparison shopping services. ${ }^{17}$ The accusation is that Google placed results from its own 'Google Shopping' service (previously called 'Froogle' and 'Google Product Search') more prominently on the search engine result page ('SERP') than justified by their 'organic' algorithmic score when users searched for a particular product on the general Google web search engine. ${ }^{18}$ On 27 August 2015, Google filed its response. ${ }^{19}$

\section{INTERNATIONAL JURISDICTION}

With regard to the international reach of European competition law, there is hardly any doubt that Google's allegedly infringing conduct is subject to EU competition law. Even though there is some debate what test is applicable to determine the international reach of European competition law, none of the tests under discussion would deny jurisdiction in the Google case.

\section{A Effects Doctrine}

International jurisdiction to prescribe is obvious if the qualified effects test is applicable. The alleged conduct of displaying links to Google Shopping results

16 European Parliament, Motion for a Resolution to Wind Up the Debate on the Statement by the Commission pursuant to Rule 132(2) of the Rules of Procedure on Supporting Consumer Rights in the Digital Single Market, B8-0286/2014 (24 November 2014) 5-6 [10]-[11]. This resolution was rightly dismissed as political posturing: James Kanter, 'EU Parliament Passes Measure to Break Up Google in Symbolic Vote', The New York Times (online), 27 November $2014 \quad<$ http://www.nytimes.com/2014/11/28/business/international/goo gle-european-union.html>; Zack Whittaker, 'Could Europe Really Break Up Google? A Look at What's Possible - And Likely', Fortune (online), 5 December 2014 <https://perma.cc/ZH5K-NBPZ?type=source>. But see Andreas Geiger, 'Thou Shalt Not Dominate' (2015) 36 European Competition Law Review 128. Andreas Geiger's article supports the resolution and does not declare any conflicts of interest.

17 See European Commission, 'Antitrust: Commission Sends Statement of Objections to Google on Comparison Shopping Service; Opens Separate Formal Investigation on Android' (Press Release, IP/15/4780, 15 April 2015) <http://perma.cc/YY8D-MF73> ('Press Release IP/15/4780'); European Commission, 'Antitrust: Commission Sends Statement of Objections to Google on Comparison Shopping Service' (Fact Sheet, MEMO/15/4781, 15 April 2015) <http://perma.cc/P9NA-4VHH> ('MEMO 15/4781'). The press release and fact sheet emphasise that the Commission leaves open the possibility of addressing the preferential treatment in relation to Google services other than comparison shopping, as well as the other three competition concerns, at a later stage.

18 See Press Release IP/15/4780, above n 17; MEMO 15/4781, above n 17.

19 See Kent Walker, 'Improving Quality Isn’t Anti-Competitive' on Google Europe Blog (27 August 2015) <http://perma.cc/QU2D-82DG>. 
more prominently in the Google general search results than its competitors' links has direct, substantial and foreseeable effects on competition between Google and its rivals such as Amazon, eBay or Foundem in the EU. Whether these effects are anti-competitive is a question for the substantive assessment, not for the determination of international jurisdiction to prescribe.

It is, however, not yet settled that the effects doctrine is the applicable test to determine the international reach of EU competition law. ${ }^{20}$ The Commission and Advocates General have long argued in favour of an effects test in EU competition law, ${ }^{21}$ following the effects doctrine firmly established in US antitrust law since United States $v$ Aluminium Co of America ('Alcoa'). ${ }^{22}$ However, from the beginning, the United Kingdom had objections against the pure effects test ${ }^{23}$ because it extends the objective territoriality principle accepted in SS Lotus (France v Turkey) ('Lotus') ${ }^{24}$ from physical, uni-directional

20 See Florian Wagner-von Papp, 'Competition Law and Extraterritoriality' in Ariel Ezrachi (ed), Research Handbook on International Competition Law (Edward Elgar, 2012) 21, 42-9; Damien Geradin, Marc Reysen and David Henry, 'Extraterritoriality, Comity, and Cooperation in EU Competition Law' in Andrew T Guzman (ed), Cooperation, Comity, and Competition Policy (Oxford University Press 2011) 21. For a discussion more generally on extraterritorial application of EU law, see Joanne Scott, 'Extraterritoriality and Territorial Extension in EU Law' (2014) 62 American Journal of Comparative Law 87; Joanne Scott, 'The New EU “Extraterritoriality”' (2014) 51 Common Market Law Review 1343.

21 Décision de la Commission du 24 juillet 1969 relative à une procédure au titre de l'article 85 du traité CEE (IV/26.267 - Matières colorantes) [Commission Decision of 24 July 1969 relating to a Proceeding under Article 85 of the CEE Treaty (IV/26/267 — Dyestuffs)] [1969] OJ L 195/11, 16 ('Dyestuffs'). Also, see the Opinion of Advocate General Mayras in: Imperial Chemical Industries Ltd v Commission of the European Communities (C-48/49) [1972] ECR 619, 668-91 ('ICI v Commission'). See also Commission Decision of 19 December 1984 relating to a Proceeding under Article 85 of the EEC Treaty [1985] OJ L 85/1, 14 [79]. Also, see the opinion of Advocate General Darmon in: A Ahlström Osakeyhtiö v Commission of the European Communities (Joined Cases C-89/85, C-104/85, C-114/85, C-116/85, C-117/85, C-125/85, C-126/85, C-127/85, C-128/85 and C-129/85) [1988] ECR 5193, 5214 [3] ('Wood Pulp I').

22 United States of America v Aluminum Co of America, 148 F 2d 416, 443-4 (2 ${ }^{\text {nd }}$ Cir, 1945) ('Alcoa').

23 In Dyestuffs, the United Kingdom submitted an aide-mémoire of 20 October 1969. For a reprint of the aide-mémoire, see A V Lowe, Extraterritorial Jurisdiction: An Annotated Collection of Legal Materials (Grotius Publications, 1983) 144-7. In Wood Pulp I, it was again the UK that objected to the effects test: Wood Pulp I [1988] ECR 5193, 5214 [3]. Also, see Note No 196 of the British Embassy at Washington, DC, which was presented to the US Department of State on July 27: Geoffrey Marston (ed), 'United Kingdom Materials on International Law 1978' (1978) 49 British Yearbook of International Law 329, 390-1. It states that 'in the present state of international law there is no basis for the extension of one country's antitrust jurisdiction to activities outside that country by foreign nationals'. Today, it is nearly exclusively commentators from the Commonwealth who raise doubts about the legitimacy of the effects test in competition law. Doubts are expressed, for example, in: Brendan J Sweeney, The Internationalisation of Competition Rules (Routledge, 2010) 245-6; A Vaughan Lowe 'Extraterritorial Jurisdiction: The British Practice' (1988) 52 Rabels Zeitschrift für ausländisches und internationales Privatrecht 157, 179. Richard Whish and David Bailey note the traditional reluctance of the UK to recognise the effects test but also the possible change in attitude indicated in the Enterprise and Regulatory Reform Act 2013 (UK): Richard Whish and David Bailey, Competition Law (Oxford University Press, $8^{\text {th }}$ ed, 2015) 533.

24 SS Lotus (France v Turkey) (Judgment) [1927] PCIJ (ser A) No 10 ('Lotus'). 
effects to more diffuse economic effects. ${ }^{25}$ As a consequence of these objections, the Court of Justice of the European Union ('CJEU' or 'the Court') has never fully embraced the effects test. Instead it has resorted to supposedly less controversial means such as requiring the 'implementation' of the infringing conduct on EU territory ${ }^{26}$ and, where necessary, treating parent and subsidiaries as a single economic entity. ${ }^{27}$

In contrast to the CJEU, the General Court (the first instance court of the EU) first applied the qualified effects test in Gencor $v$ Commission ('Gencor'), ${ }^{28}$ although some commentators - not coincidentally coming from the UK - claim that in Gencor, 'the General Court avoided the adoption of the effects doctrine'. ${ }^{29}$ The General Court's 2014 judgment in Intel v Commission ('Intel') overcame any remaining doubts as to that court's willingness to employ an effects test. In Intel, the General Court expressly stated, this time in the context of an infringement of art 102 of the Treaty on the Functioning of the European Union ('TFEU'), ${ }^{30}$ that the implementation test and the qualified effects test are alternative tests under which international jurisdiction can be established independently. ${ }^{31}$

Intel has challenged the General Court's assessment in its appeal to the CJEU. ${ }^{32}$ It remains to be seen whether the CJEU will finally take the plunge and approve the General Court's adoption of the effects test as the relevant test for international jurisdiction. It should. Whatever the status of the effects test was in 1945, when Alcoa established the effects doctrine for the US, 33 and whether or not one sees the effects test for economic law justified by the acceptance of the effects test for physical effects in the Lotus decision, today the sheer number of

25 For the differences between the objective territoriality principle and the pure effects doctrine, see F A Mann, 'The Doctrine of Jurisdiction in International Law' (1964) 111 Recueil des Cours 9, 104: "The "effect" within the meaning of the Alcoa ruling does not amount to an essential or constituent part of the restraint of trade, but is an indirect and remote repercussion of a restraint'. Marek Martyniszyn rightly emphasises the distinction. See Marek Martyniszyn, 'On Extraterritoriality and the Gazprom Case’ (2015) 36 European Competition Law Review 291, 291-2.

26 Wood Pulp I [1988] ECR 5193, 5243 [16]-[18]. See Mann, above n 25, 105 n 219. F A Mann qualified his rejection of the view that effects do not justify international jurisdiction by conceding the possibility of an exception for cases 'in which the cartel is actually operated and consummated within the importing State by the creation of a permanent sales organisation or in some similar manner'.

27 ICI v Commission [1972] ECR 619, 661-3 [125]-[142]. See especially at 662 [134].

28 Gencor Ltd v Commission of the European Communities (T-102/96) [1999] ECR II-753, 785-8 [90]-[101] ('Gencor').

29 Richard Whish and David Bailey, Competition Law (Oxford University Press, $7^{\text {th }}$ ed, 2012) 500. It is clear that as a matter of public international law, the General Court considered effects sufficient. It is another matter whether the Court considered the conflicts rules implicit in Council Regulation (EEC) No 4064/89 of 21 December 1989 on the Control of Concentrations between Undertakings to require more. See Gencor [1999] ECR II-753, 782-4 [78]-[88]; Council Regulation (EEC) No 4064/89 of 21 December 1989 on the Control of Concentrations between Undertakings [1989] OJ L 395/1.

30 Consolidated TFEU [2012] OJ C 326/47.

31 Intel Corp v European Commission (General Court of the European Union, T-286/09, 12 June 2014) [231]-[244].

32 Appeal Brought on 28 August 2014 by Intel Corporation against the Judgment of the General Court (Seventh Chamber, Extended Composition) Delivered on 12 June 2014 in Case T-286/09: Intel Corporation v European Commission [2014] OJ C 395/25, 26. This is the fifth ground of appeal.

33 Alcoa, 148 F 2d 416, 443-4 (2 ${ }^{\text {nd }}$ Cir, 1945). 
antitrust jurisdictions that have adopted the effects doctrine makes it a fruitless endeavour to argue that it is incompatible with public international law. ${ }^{34}$ Going in alphabetical order, at least the following jurisdictions are said to have adopted the effects test: Albania, Argentina, Austria, Belgium, Brazil, China, Croatia, the Czech Republic, Denmark, France, Germany, Greece, Hungary, Iceland, India, Israel, Japan, Jordan, Latvia, Lithuania, Macedonia, Norway, Peru, Portugal, Romania, Russia, Singapore, Slovakia, South Africa, South Korea, Spain, Switzerland, Turkey, the Ukraine and, of course, the United States of America. ${ }^{35}$ In many further jurisdictions, such as Canada, Italy, Ireland, Luxembourg, the Netherlands and Sweden, it is not entirely clear if the effects test or the implementation test governs. ${ }^{36}$

The Harper Review of competition policy in Australia has recently suggested that the reach of Australian competition law should also be extended to encompass 'conduct outside Australia by any person in so far as the conduct relates to trade or commerce', where 'trade or commerce' is defined as 'trade or commerce within Australia or between Australia and places outside Australia'. ${ }^{37}$

\section{B Implementation Test}

Even if one denied the effects doctrine's compatibility with public international law, the EU's international jurisdiction for the Google case can also be established under the (minimally more demanding) implementation test applied in A Ahlström Osakeyhtiö v Commission of the European Communities ('Wood Pulp I'). ${ }^{38}$

The infringing conduct is, with a grain of salt, the determination of the relative search ranking and display of Google's and its competitors' specialised result links, be it through an 'organic' or some 'artificial' ingredient in Google's 'secret sauce'. In Google Spain SL v Agencia Española de Protección de Datos (AEPD) ('Google Spain') - the data protection case (in)famous for recognising a 'right to be forgotten' - Google had argued that the processing of personal data was done exclusively by Google Inc and not by the national subsidiary. In that case, the national court had found that the location of the servers on which

34 Martyniszyn, above n 25, 292; Wagner-von Papp, 'Competition Law and Extraterritoriality’, above n 20, 40-1.

35 For references, see the national reports in: Michael J Fanelli et al (eds), Competition Laws outside the United States (ABA, $2^{\text {nd }}$ ed, 2011) vols 1-2; Maher M Dabbah and Barry E Hawk (eds), Anti-Cartel Enforcement Worldwide (Cambridge University Press, 2009) vols 1-3; Cedric Ryngaert, Jurisdiction over Antitrust Violations in International Law (Intersentia, 2008) 53-4. See also Florian Wagner-von Papp and Wolfgang Wurmnest, 'Sachlicher, zeitlicher und internationaler Anwendungsbereich des Wettbewerbsrechts [Substantive, Temporal and International Scope of Competition Law]' in Joachim Bornkamm, Frank Montag and Franz Jürgen Säcker (eds), Münchener Kommentar - Europäisches und Deutsches Wettbewerbsrecht: Kartellrecht Missbrauchs- und Fusionskontrolle [Munich Comment - European and German Competition Law: Antitrust Abuse and Merger Control] (C H Beck, $2^{\text {nd }}$ ed, 2015) vol 1, 530, 547-8 [1548] nn 4072-107. Note the important proviso that in many of these jurisdictions the effects principle may only be law in the books without actual enforcement practice.

36 See above $\mathrm{n} 35$ and accompanying text.

37 See Ian Harper et al, 'Competition Policy Review — Final Report' (Report, March 2015) 57-8, 502.

38 Wood Pulp I [1988] ECR 5193. 
the information gathered by the web crawlers is temporarily stored is kept secret, but that ' $[\mathrm{t}$ ]he Google group has recourse to its [national subsidiary] for promoting the sale of advertising space generated on the website "www.google.com"”. 39 Taking into account Google's two-sided business model, the CJEU considered for purposes of determining the territorial scope of Directive 95/46/EC ('Data Protection Directive') ${ }^{40}$ that

the activities of the operator of the search engine and those of its establishment situated in the Member State concerned are inextricably linked since the activities relating to the advertising space constitute the means of rendering the search engine at issue economically profitable and that engine is, at the same time, the means enabling those activities to be performed. ${ }^{41}$

Of course, the issue in Google Spain was different from the antitrust case. The objectives of the Data Protection Directive differ from those of competition law, and the Data Protection Directive's territorial scope is not defined in terms of 'implementation' - the statutory language to be interpreted in Google Spain was whether the 'processing is carried out in the context of the activities of an establishment of the controller on the territory of the Member State'. ${ }^{42}$

Nevertheless, Google Spain is indicative that the Court is willing to take into account the promotional activities in the territory of a member state to reach the (possibly extraterritorial) data processing side of the two-sided business model. Combined with the broad interpretation of 'implementation' that the Court applied in the Wood Pulp I judgment — which did not differ substantially from an effects test - and the longstanding treatment of parent and subsidiary as a single economic unit, this gives an inkling that the Court would not hesitate to consider Google's self-preferential treatment in displaying Google specialised result links to be implemented within the EU, based on the 'inextricable link' between the search side and the conduct of Google's subsidiaries on the advertising side, which are active in intra-EU sub-markets. 43

\section{Nationality Principle}

One might be tempted to rely on the nationality principle to establish international jurisdiction. One could rely on the combination of the two-sided business model rationale with the single economic unit doctrine to consider Google's intra-EU subsidiaries as 'EU nationals'. However, nationality as such is not a genuine link that establishes international jurisdiction in competition law, because the nationality criterion lacks 'a close connection between the legislating

39 Google Spain SL v Agencia Española de Protección de Datos (AEPD) (Court of Justice of the European Union, Case C-131/12, 13 May 2014) [43] ('Google Spain').

40 Directive 95/46/EC of the European Parliament and of the Council of 24 October 1995 on the Protection of Individuals with regard to the Processing of Personal Data and on the Free Movement of Such Data [1995] OJ L 281/31.

41 Google Spain (Court of Justice of the European Union, Case C-131/12, 13 May 2014) [56].

42 Ibid [6].

43 The market for online advertising space is to be defined along national or linguistic borders within the European Economic Area. For the narrow market definition on the advertising side, see Google/DoubleClick - Regulation (EC) No 139/2004 Merger Procedure (European Commission, Case No COMP/M.4731, 11 March 2008) 25 [83]-[84] ('Google/DoubleClick Merger Decision'). 
State and the subject-matter of the legislation'. ${ }^{44}$ Jurisdictions enacting competition laws care about restrictive conduct and its effects, not about who infringes the law.

\section{Limits to the Exercise of International Jurisdiction}

If we take the effects test, or at least the implementation test, as accepted in public international law, there is still the question whether public international law puts other limits to the exercise of international jurisdiction. Courts have discussed, in particular, the principle of non-interference. However, in the antitrust context, they have generally reduced this principle at most to the situation in which there is a 'true conflict', where one jurisdiction requires the firm to engage in conduct that is prohibited by the other jurisdiction; merely permitting such conduct is deemed insufficient to trigger the principle of non-interference. ${ }^{45}$ The mere fact that the Federal Trade Commission ('FTC') in the US considered and rejected antitrust intervention against Google based on similar concerns ${ }^{46}$ is insufficient to trigger the principle of non-interference.

Courts have toyed from time to time with the idea of balancing tests based on comity considerations in antitrust cases such as Timberlane Lumber Co v Bank of America or Mannington Mills Inc $v$ Congoleum Corp. ${ }^{47}$ If this view had prevailed, this could possibly have been an argument for challenging the EU's jurisdiction in the Google case - though it is difficult to predict what the result of the multi-factor balancing exercise of incommensurate factors would be. However, precisely because of the unpredictability, lack of justiciability and unworkability of a multi-factor balancing exercise of incommensurate, politically

44 Mann, above n 25, 97: Mann rejects the nationality principle as a basis for international jurisdiction for restrictive practices.

45 Wood Pulp I [1988] ECR 5193, 5214 [20].

46 See, eg, Federal Trade Commission, 'Google Agrees to Change Its Business Practices to Resolve FTC Competition Concerns in the Markets for Devices Like Smart Phones, Games and Tablets, and in Online Search' (Press Release, 3 January 2013), $<$ https://perma.cc/2QLU-HZXU?type=source> ('FTC Press Release'). See also the famous (semi-) leaked Federal Trade Commission Google memorandum that was leaked to and published online by the Wall Street Journal: Federal Trade Commission, 'Memorandum' (Memorandum No 111-0163, 8 August 2012) <http://perma.cc/8NDT-YR2W> ('FTC Memorandum'). Note that only even page numbers of the FTC Memorandum were leaked and published.

47 Timberlane Lumber Co $v$ Bank of America, 549 F 2d 597, 614-5 (9 ${ }^{\text {th }}$ Cir, 1976); Mannington Mills Inc v Congoleum Corp, 595 F 2d 1287, 1294-8 (3 ${ }^{\text {rd }}$ Cir, 1979); Spencer Weber Waller, 'The Twilight of Comity' (2000) 38 Columbia Journal of Transnational Law 562. 
charged factors, case-to-case balancing tests have not prevailed as a legal requirement. 48

While courts will not engage in interest balancing as a matter of law, balancing tests may come into play when it comes to discretionary decisions by competition authorities whether or not to prosecute a case. ${ }^{49}$ The Agreement between the Government of the United States of America and the Commission of the European Communities regarding the Application of Their Competition Laws ('Positive Comity Agreement') ${ }^{50}$ does not put substantial hurdles in the way of an EU antitrust investigation into Google. Procedurally, the Commission was obliged to notify the US far enough in advance of the Statement of Objections, and will have to notify the US again far enough in advance of a decision, to take into account the US' views. ${ }^{51}$ The Commission will have to consider the factors listed in art VI(3) of the Positive Comity Agreement, in particular when it comes to the decision stage (art VI(2)). However, all the Commission is legally obliged to do is to 'seek ... to take into account the important interests of the [US]' ' $[\mathrm{w}]$ ithin the framework of its own laws and to the extent compatible with its important interests'. 52 Should the Commission come to the conclusion in its substantive assessment that Google's conduct substantially restricts competition in the EU, the Positive Comity Agreement would not prevent a prohibition decision or sanctions, although the US' interests would have to be taken into

48 It is controversial to what extent balancing considerations are still permissible after Hartford Fire Insurance Co v California. See Hartford Fire Insurance Co v California, 509 US 764, 798-9 (1993). For a discussion, see, eg, In Re Vitamin C Antitrust Litigation, 810 F Supp 2d 522, 542-4 (ED NY, 2011). In F Hoffmann-La Roche Ltd v Empagran, the US Supreme Court considered the balancing approach based on comity 'too complex to prove workable': F Hoffmann-La Roche Ltd v Empagran SA, 542 US 155, 168 (2004). Similarly, see Edward T Swaine, 'Cooperation, Comity, and Competition Policy: United States' in Andrew T Guzman (ed), Cooperation, Comity, and Competition Policy (Oxford University Press, 2010) 3, 9-14. '[T]he kitchen sink approach suggested by the courts and by the Restatement (Third) was a challenge to administer': at 11-12. Edward Swaine rightly points out that balancing tests may continue to have some sway when it comes to procedural and evidentiary issues: at 13.

49 Waller, above n 47, 578.

50 Agreement between the Government of the United States of America and the Commission of the European Communities regarding the Application of Their Competition Laws [1995] OJ L 95/47 ('Positive Comity Agreement'). This agreement was approved on behalf of the European Community and the European Coal and Steel Community by Decision 98/386/EC, ECSC of the Commission of 29 May 1998 concerning the conclusion of the agreement between the European Communities and the US Government on the application of positive comity principles in the enforcement of their competition laws: Decision of the Council and of the Commission of 29 May 1998 concerning the Conclusion of the Agreement between the European Communities and the Government of the United States of America on the Application of Positive Comity Principles in the Enforcement of Their Competition Laws [1998] OJ L 173/26.

51 FTC Memorandum, above n 46, 2: 'FTC staff has coordinated closely with EC staff throughout the course of our parallel investigations'.

52 Positive Comity Agreement [1995] OJ L 95/47, art VI. 
account. ${ }^{53}$ Even with bilateral agreements in place, it remains true that "“comity" sounds good and does little work'. ${ }^{54}$

\section{E Bias towards Over-Enforcement because of Multiple Enforcement}

Given the nearly universal application of the effects principle - or at least the implementation test - and the narrow scope of limiting principles such as the principle of non-interference and comity, public international law will not be a stumbling block for the Commission's Google investigation. Nevertheless, the Google case exemplifies both the benefits and the disadvantages of the cumulation of competition investigations that are often the result of the effects doctrine in a world with scores of jurisdictions with competition laws.

On the one hand, in a world with sovereign nations whose populations have heterogenous preferences it must be possible for a competition regime (in Google: the EU) to revisit a case even where another competition regime, based on its own preferences, has already looked at the case (here: the US). In addition, jurisdictions also differ with regard to the institutional background. The facts of the case or competitive conditions may differ in different jurisdictions as well, as is the case here, for example, in terms of the prevalence of the use of Google as a search engine by consumers. Furthermore, overlaps of the regimes help to prevent under-enforcement that could result if competition law enforcement were left exclusively in the hands of the 'home jurisdiction' - perhaps due to successful lobbying efforts or beggar-thy-neighbour-type strategic competition policies.

On the other hand, cumulative investigations clearly result in a systematic bias in favour of over-enforcement. ${ }^{55}$ Even where multiple enforcers have decided that a given conduct is pro-competitive, it takes only one enforcer to decide that it is anti-competitive to make life for the undertaking difficult. This was not a big problem in a world with one or two active competition enforcers.

53 Generally on the toothlessness of bilateral agreements, see Philip Marsden, 'The Curious Incident of Positive Comity - The Dog That Didn't Bark (and the Trade Dogs That Just Might Bite)' in Andrew T Guzman (ed), Cooperation, Comity, and Competition Policy (Oxford University Press, 2010) 301, 309-10; Philip Marsden, “Jaw-Jaw” not "Law-Law" - From Treaties to Meetings: The Increasing Informality and Effectiveness of International Cooperation' in Ariel Ezrachi (ed), Research Handbook on International Competition Law (Edward Elgar, 2012) 110, 115-21. In contrast, Robert Brewington appears to place more faith in bilateral agreements in the Google context: Robert Brewington, 'A Case for Global Cooperation when Enforcing United States Antitrust and European Union Competition Laws against Modern Technology Companies' (2014) 48 University of San Francisco Law Review 501, 518-31. Brewington argues that duplicative enforcement could be contained by bilateral agreements without, however, discussing the existing EU-US Positive Comity Agreement.

54 In the US context, see Eleanor M Fox, 'Antitrust without Borders: From Roots to Codes to Networks' in Andrew T Guzman (ed), Cooperation, Comity, and Competition Policy (Oxford University Press, 2010) 265, 269. For similar sentiments for the EU-US Positive Comity Agreement, see Geradin, Reysen and Henry, above n 20, 30-1; Swaine, above n 48, 15-17. See especially at 17: 'Few discussions offer any clear depiction of how past disputes could have been resolved under the comity protocols - without, that is, wishing away divergent political and economic interests and substantive disagreements'.

55 Andrew Guzman, 'Competition Law and Cooperation: Possible Strategies' in Andrew T Guzman (ed), Cooperation, Comity, and Competition Policy (Oxford University Press, 2010) 345, 349-50; Andrew Guzman, 'The Case for International Antitrust' (2004) 22 Berkeley Journal of International Law 355, 359-60. See also Wagner-von Papp, 'Competition Law and Extraterritoriality', above n 20, 56-7. 
If, for example, any given competition authority has a probability of a false positive of five per cent, in a world with two enforcers there is a probability of 'only' 9.75 per cent that either or both erroneously prohibit the conduct. ${ }^{56}$ In a world where 20 enforcers look at the conduct, the probability that at least one erroneously prohibits the conduct rises to some 64 per cent. ${ }^{57}$

In a world with heterogeneous preferences, the benefits of multiple enforcement arguably outweigh the benefits of alternative solutions such as developing uniform international standards or meta-rules for deciding just one lead jurisdiction.

However, the systematic bias in favour of over-enforcement implicit in multiple enforcement should make enforcers in any given case rather err on the side of under-enforcement. And Google's conduct is scrutinised by multiple enforcers. Beside the FTC $^{58}$ and the European Commission ${ }^{59}$ investigations, there have already been a number of private actions in the US 60 and the UK. ${ }^{61}$ The Competition Commission of India has submitted a preliminary report finding an abuse of a dominant position. ${ }^{62}$ Brazil is reported to look into

$56 \mathrm{P}=1-0.95^{2}=0.0975$, or $\mathrm{P}(\mathrm{A} \cup \mathrm{B})=\mathrm{P}(\mathrm{A})+\mathrm{P}(\mathrm{B})-\mathrm{P}(\mathrm{A} \cap \mathrm{B})$, where $\mathrm{P}(\mathrm{A})=\mathrm{P}(\mathrm{B})=0.05$ and $\mathrm{P}(\mathrm{A} \cap \mathrm{B})=\mathrm{P}(\mathrm{A}) \mathrm{P}(\mathrm{B})$, so that $\mathrm{P}(\mathrm{A} \cup \mathrm{B})=0.05+0.5-0.0025=0.0975$. For the qualification on independence of probabilities, see below $n 57$.

$57 \mathrm{P}=1-0.95^{20}=0.6415$. Of course, this assumes that the probabilities are independent. In reality, there is likely to be Bayesian updating where other enforcers have already scrutinised the conduct. For example, where 19 enforcers have looked at the conduct and found no harm, the $20^{\text {th }}$ enforcer will likely double- and triple-check the analysis before it reaches a finding of infringement.

58 See, eg, FTC Press Release, above n 46. See also FTC Memorandum, above n 46.

59 See above Part II.

60 See, eg, Kinderstart.com LLC v Google Inc (ND Cal, No C 06-2057 JF (RS), 16 March 2007). Here, the Court granted motion to dismiss for failure to state a claim without leave to amend, after having previously granted a motion to dismiss with leave to amend. See also Kinderstart.com LLC v Google Inc (ND Cal, No C 06-2057 JF (RS), 13 July 2006); Person $v$ Google Inc ( $9^{\text {th }}$ Cir, No 07-16367, 24 September 2009). The Court affirmed the District Court's Rule 12(b)(6) dismissal in Person v Google Inc for failure to state a claim: Person v Google Inc (ND Cal, No 06-7297 JF (RS), 25 June 2007). In this case, the plaintiff had previously sued in New York and the case had been transferred. See Person $v$ Google Inc, 456 F Supp 2d 488 (SD NY, 2006); TradeComet.com LLC v Google Inc, 647 F 3d 472 (2 ${ }^{\text {nd }}$ Cir, 2011). In TradeComet.com LLC v Google Inc, the Court affirmed the District Court's Rule 12(b) dismissal for lack of subject matter jurisdiction or improper venue based on forum selection clause, not requiring transfer of the case to the proper venue: TradeComet.com LLC v Google Inc, 693 F Supp 2d 370 (SD NY, 2010). See also Feitelson $v$ Google Inc, 80 F Supp 3d 1019 (ND Cal, 2015). In this case, the Court granted motion to dismiss for failure to state a claim relating, however, to alleged anti-competitive agreements between Google and mobile phone manufacturers, more akin to the Commission's investigation into Android, which opened on 15 April 2015. See EU Commission Investigation into Android, above $\mathrm{n} 1$.

61 Infederation Ltd v Google Inc [2013] EWHC 2295 (Ch). In this action, Foundem seeks damages from Google for conduct now mentioned in the Statement of Objections by the Commission. See also Streetmap.EU Ltd v Google Inc (Case No HC-2013-000090). This is a case in the Chancery Division of the High Court of England and Wales at the time of writing, in which Streetmap.EU complains of the self-preferencing of Google Maps in the search results and diversion of traffic away from Streetmap.EU's website. On this case, see Samuel Gibbs, 'Google Taken to Court by Streetmap over “Anticompetitive” Search Abuse’, The Guardian (online), 4 November 2015 <http://perma.cc/M44X-3F7B>.

62 Conor Dougherty and Mark Scott, 'Google Antitrust Inquiries Spread over Globe, With India the Latest Problem', The New York Times (online), 1 September 2015 <http://www.nytimes.com/2015/09/02/technology/google-antitrust-investigations-spread-acr oss-the-globe.html>; James Crabtree, 'Google under Fire for India Market Abuse', Financial Times (online), 31 August 2015. 
self-preferencing claims. ${ }^{63}$ The French Autorité de la Concurrence [Competition Authority] is looking into an alleged case of exclusion of an undertaking from AdWords. ${ }^{64}$ An antitrust investigation against Google has been opened and closed, inter alia, in South Korea. ${ }^{65}$ In Germany, a complaint as to scraping was dismissed as largely unrelated to competition law ${ }^{66}$ and, more importantly in our context, an application for an injunction in a private action brought by a provider of weather forecasts who complained of Google's self-preferencing in the form of displaying prominently its weather box before the organic search results was also dismissed. ${ }^{67}$ The new platform 'Google Redress \& Integrity Platform', established by plaintiff's firm Hausfeld \& Co is already looking for harmed consumers. ${ }^{68}$ If United States $v$ Microsoft ('Microsoft') 69 is anything to go by, it is also to be expected that there will be further public and private actions in numerous other jurisdictions. ${ }^{70}$

Accusations that the EU investigation into Google's conduct is driven by protectionist reasons are unfounded. ${ }^{71}$ It is true that the misguided use of the commitment procedure led to political attempts to influence the antitrust case, especially by German and French politicians, who sought political capital by piling onto Google's troubles with regard to privacy and tax issues and by endearing themselves to Axel Springer, the publisher of the leading German tabloid and complainant in the Google case; without this political influence the antitrust case may well have been resolved in the commitment procedure. ${ }^{72}$ While the commitment procedure is a largely discretionary negotiation, in which

63 Dougherty and Scott, above n 62.

64 See République française Autorité de la Concurrence [French Republic Competition Authority], Décision $n^{\circ} 15-D-13$ du 9 septembre 2015 relative à une demande de mesures conservatoires de la société Gibmedia [Decision No 15-D-13 of 9 September 2015 on an Application for Interim Measures of the Company Cibmedia], 9 September 2015 $<$ http://perma.cc/7G2M-3AB4>. Here the authority denied an interim injunction but found it likely that Google has a dominant position and that the exclusion from AdWords was based on a policy that was not objective, transparent or non-discriminatory and that it may infringe art L420-2 of the Code du Commerce: at 34 [180]-[181]. See also Code de commerce [Commercial Code] (France) art L420-2.

65 Dougherty and Scott, above n 62 (relating to Android, so being closer to the Commission's investigation opened on 15 April 2015).

66 Bundeskartellamt, ‘Bundeskartellamt Takes Decision in Ancillary Copyright Dispute’ (Press Release, 9 September 2015) <https://perma.cc/P9BF-Z8WQ?type=source>. See Bundeskartellamt, 'Complaint by VG Media Not Sufficient to Institute Formal Abuse of Dominance Proceedings against Google’ (Press Release, 22 August 2014) $<$ https://perma.cc/C78U-YVDW?type=source $>$.

67 Landgericht Hamburg [Regional Court of Hamburg], Az 408 HKO 36/13, 4 April 2013. The decision in German and an unofficial courtesy translation into English are available at: TaylorWessing, Taylor Wessing für Google erfolgreich [Taylor Wessing Win for Google] (4 June 2013) <http://perma.cc/PXY5-RLC4>. The decision doubted that Google was dominant, but ultimately left the question undecided because it considered the conduct as not abusive.

68 Robin Wauters, Another Fierce Foe for Google in Europe: Meet GRIP, Tech.eu $<$ http://perma.cc/283E-TEWX $>$.

69 United States of America v Microsoft, 253 F 3d 34 (DC Cir, 2001) ('Microsoft').

70 See also Renda, above n 3, 12-13.

71 For such an accusation, see, eg, Kara Swisher, White House. Red Chair. Obama Meets Swisher (15 February 2015) Re/code <http://perma.cc/PVH4-V24J>; Murad Ahmed, Duncan Robinson and Richard Waters, 'Obama Attacks Europe over Technology Protectionism’, Financial Times (online), 16 February 2015.

72 Nazzini, above n 1, 303-4; Stone and Silver, above n 3. 
such political influence is possible, the infringement procedure is a rule-bound and largely technocratic exercise conducted by the Directorate-General for Competition and free from political pressures. The idea that the Commission's antitrust case is motivated by protectionism is belied by the fact that the major complainants in Google are US firms, as are most firms that would benefit from enforcement action, such as Amazon, eBay, Expedia, Microsoft, TripAdvisor or Yahoo!; even the 'German' shopping comparison website Guenstiger.de is owned by the US-based Nextag. ${ }^{73}$ Also, while it is true that the FTC reached a settlement and saw no further cause for action, its findings were hardly such that it would be vexatious to look at Google's conduct in other jurisdictions: it considered the self-preferencing accusation 'a close call'. ${ }^{74}$ In addition, Google's search share in Europe is substantially higher than in the US, so that, quite apart from the generally more interventionist antitrust regime in the EU (which is more concerned with false negatives than with false positives), even the facts of the case differ on both sides of the Atlantic, making the FTC investigation an imperfect proxy for European concerns. Overall, it seems that it is mainly Google's US competitors that try to use the EU antitrust system, which is more aggressive towards dominant firms, as a tool to gain a competitive advantage. This is hardly European protectionism.

While not driven by protectionism, antitrust concerns against Google's self-preferencing should be approached cautiously to avoid over-enforcement that may result from multiple enforcement. The next Part will look at the merits of the Google case.

\section{THE MERITS OF THE CASE}

Without knowing the details of the allegations and supporting evidence, it is impossible to reach a firm opinion on the merits of the case (although this has not stopped commentators from trying). My prior belief is that Google is not dominant and that Google's conduct in relation to self-preferencing is not a concern for antitrust enforcement. Below, I will explain why I hold this prior belief and what evidence it would take to change it.

\section{A Market Definition and Shares}

\section{Preliminary Observations on Search Shares in a Two-Sided Business} Model

The first question is whether Google is in a dominant position. Given Google’s 90 per cent plus share of searches in various EU member states, ${ }^{75}$ often

\footnotetext{
73 See Foo Yun Chee and Eric Auchard, 'EU Antitrust Case against Google Based on 19 Complainants: Sources', Reuters (online), 27 April 2015, <http://perma.cc/Q6Q4-C4CL>. This article identified complainants and added that 'Yelp said that US rivals have been a driving force behind the EU action'.

74 FTC Memorandum, above n 46, 18.

75 For example, see the statistics available at: StatCounter, StatCounter Global Stats <http://perma.cc/KG2D-ZJGM>.
} 
interpreted as market share, ${ }^{76}$ this could appear to be a rhetorical question. It is not. To confuse market share with dominance is a category error.

It is true that high market shares can be 'a useful first indication' 77 for the market structure and market power, but this does not mean that a very high market share is conclusive proof of market power. A monopoly with one firm holding a 100 per cent market share on a market that is perfectly contestable, that is, hit-and-run entry into the market is possible because there are no sunk costs of entry, does not have any market power. If the monopolist tried to raise price over marginal cost, others would enter the market and drive the price back down to marginal cost. Such a monopolist has a 100 per cent market share, but is not in

a position of economic strength ... which enables it to prevent effective competition being maintained on the relevant market by giving it the power to behave to an appreciable extent independently of its competitors, customers and ultimately of its consumers. ${ }^{78}$

Two provisos are necessary. First, the CJEU has occasionally indicated that:

The possession, over a long period, of a very large market share constitutes in itself, save in exceptional circumstances, proof of the existence of a dominant position (Hoffman-La Roche [sic] ... ) and that market shares of more than 50\% constitute very large market shares (Case AKZO ... ). ${ }^{79}$

76 See, eg, Ioannis Lianos and Evgenia Motchenkova, 'Market Dominance and Search Quality in the Search Engine Market' (2013) 9 Journal of Competition Law \& Economics 419, 423; Geiger, above n 16, 130; Benjamin Edelman, 'Does Google Leverage Market Power through Tying and Bundling?' (2015) 11 Journal of Competition Law \& Economics 365, 386-7. The relevance of the 90 (or in the US: 70) per cent 'share' figure itself has been called into question. Geoffrey A Manne and Joshua D Wright, 'Google and the Limits of Antitrust: The Case against the Case against Google' (2011) 34 Harvard Journal of Law \& Public Policy 171, 194-203, 220-33; Christian Kersting and Sebastian Dworschak, 'Google als Marktbeherrscher? — zur (geringen) Aussagekraft hoher Nutzerzahlen im Internet' [Does Google Hold a Dominant Market Position? - Addressing the (Minor) Significance of High Online User Shares] (2014) 67(16) ifo Schnelldienst 7. The arguments by Geoffrey Manne, Joshua Wright, Christian Kersting and Sebastian Dworschak against taking the 90 (US: 70) per cent figure as market shares is essentially threefold. First, the 90 per cent figure relates to the proportion of searches on the free side of the two-sided business model. See also Nazzini, above n 1, 304. Secondly, online search advertising may not be the correct market, because on the advertisers' side, offline or display advertising may be sufficiently interchangeable, and on the search user side, users search not only on general search engines but also on vertical search engines and (especially mobile) applications. Thirdly, the number of searches or impressions does not necessarily translate into revenue share. These issues will be discussed below. The argument in the text following this footnote is merely that even if we did use the 90 per cent figure to represent market shares, this would not demonstrate dominance.

77 Communication from the Commission - Guidance on the Commission's Enforcement Priorities in Applying Article 82 of the EC Treaty to Abusive Exclusionary Conduct by Dominant Undertakings [2009] OJ C 45/7, 8-9 [13] ('Commission Guidance').

78 This is the standard definition of a dominant position in the EU. See United Brands Company $v$ Commission of the European Communities (C-27/76) [1978] ECR 209, 277 [65].

79 For the synthesis of these two provisos, see, eg, AstraZeneca AB v European Commission (Court of Justice of the European Communities, C-457/10 P, 6 December 2012) 31 [176] ('AstraZeneca'). AstraZeneca refers respectively to: Hoffmann-La Roche $v$ Commission of the European Communities (C-85/76) [1979] ECR 464, 521 [41] ('Hoffmann-La Roche'); AKZO Chemie BV v Commission of the European Communities (C-62/86) [1991] ECR I-3439. 
Indeed, it is likely that any decision by the Commission or Court in the Google case would contain this phrase.

However, this phrase has never been used to reduce the investigation into dominance to a mechanistic market share calculation. ${ }^{80}$ The Commission is very well aware of this, ${ }^{81}$ and I am confident that the Commission's approach to Google's dominance is not this simplistic. It is always necessary to enquire into the question whether competitors sufficiently constrain the allegedly dominant firm's action space. ${ }^{82}$

The second proviso is that nobody claims that the market for search engines is as perfectly contestable as the market in the hypothetical above. ${ }^{83}$ Economies of scale play a role in determining user intent of a search and so the quality of the search results and consumer inertia may prevent consumers from switching; these issues will be addressed below. The contestable markets example is merely meant to illustrate that even a 100 per cent market share need not imply dominance. The more contestable a market position of the firm in question is, the less the market shares tell us about the firm's power to behave independently and therefore its dominance. ${ }^{84}$ Mark Patterson has pointed out that one factor that makes Google's position more easily contestable is that competitors could accommodate consumers switching away much more easily than in brick and mortar markets because the marginal cost of producing another search result is close to zero. ${ }^{85}$

Google's search share of about 90 per cent could be indicative of barriers to entry, market power and dominance; or it could equally well mean that the market for search engines is contestable — or, more realistically, that the existing competitors put a sufficient competitive constraint on Google — but that Google has the best product and that the high transparency on the world wide web leads practically all consumers to the best product. ${ }^{86}$

80 See, eg, Hoffmann-La Roche [1979] ECR 464, 521 [41]: '[A]lthough the importance of market shares may vary from one market to another'. See also AstraZeneca (Court of Justice of the European Communities, C-457/10 P, 6 December 2012) 31-2 [178]-[181]. AstraZeneca points to the General Court's analysis of other factors. Indeed, hardly anyone uses market shares without further analysis to establish market power. But see Edelman, 'Does Google Leverage Market Power through Tying and Bundling?', above n 76, 370-1, 386-7.

81 See Commission Guidance [2009] OJ C 45/7, 9 [15]. The Commission adds as a proviso to the indicative effect of high market shares held over a long period of time: 'However, as a general rule, the Commission will not come to a final conclusion as to whether or not a case should be pursued without examining all the factors which may be sufficient to constrain the behaviour of the undertaking'. See also Microsoft/Skype - Regulation (EC) No 139/2004 Merger Procedure (European Commission, Case No COMP/M.6281, 7 October 2011) 14 [78], 18 [99].

82 I am, of course, by far not the first one to point this out in the context of the EU Google case. See, eg, Körber, 'Common Errors regarding Search Engine Regulation', above n 15, 241; Kersting and Dworschak, above n 76; Verhaert, above n 14, 272-3.

83 For an inquiry into the contestability of online search, see Cédric Argenton and Jens Prüfer, 'Search Engine Competition with Network Externalities' (2012) 8 Journal of Competition Law \& Economics 73, 75-105. Here, the authors considered the market to be not perfectly contestable due to economies of scale in data collection. This is also discussed below.

84 See, eg, Manne and Wright, above n 76, 191; Kersting and Dworschak, above n 76, 7.

85 Mark R Patterson, 'Google and Search-Engine Market Power' (2013) 26(2) Harvard Journal of Law \& Technology (Online Paper Series) 1, $6<$ http://perma.cc/F8AW-5LBY>.

86 Nazzini, above n 1, 305. 
This is the core of Google's argument that 'competition is one click away'. One should not blindly buy into this argument - after all, they would say that, wouldn't they? On the advertisers' side of the two-sided business model, it is simply not true: on this side, viewed in isolation, Google is arguably what in European competition law is called an 'unavoidable trading partner' as far as online search advertising is concerned. ${ }^{87}$ Crucially, however, this qualification as an unavoidable trading partner on the advertising side of the market only exists as long as Google remains the primary choice for search users; this is the consequence of Google's two-sided business model. ${ }^{88}$ In a market where

87 Lianos and Motchenkova, above n 76, 429. The authors point to the French competition authority's finding 'at least for the advertisers' side of the market'. The 'unavoidable trading partner' terminology comes from: Hoffmann-La Roche [1979] ECR 464, 521 [41]. The question here is, first, whether online search advertising is a market in itself, or whether other forms of (non-search) online advertisement, or even offline advertisement, are sufficiently good substitutes. It seems plausible to me that from the advertisers' perspective user-targeted online advertising is more effective than a billboard, television or newspaper ad and that prices for online advertising are more transparently metered by the advertisements' effectiveness, but that non-search-based individualised display ads come close to search-based ads in their effectiveness. To this effect, see also Google/DoubleClick Merger Decision (Case No COMP/M.4731) 7-8 [11]-[15], 17-20 [44]-[56]; Microsoft/Yahoo! Search Business - Regulation (EC) No 139/2004 Merger Procedure (European Commission, Case No COMP/M.5727, 18 February 2010) 10-13 [61]-[87]; Verhaert, above n 14, 270-1. Thomas Hoppner shares the view that one has to distinguish between offline and online advertising, but he also advocates distinguishing search from non-search advertising and even subdivides the market for search advertising further into 'a market for horizontal and a market for vertical search advertising': Thomas Hoppner, 'Defining Markets for Multi-Sided Platforms: The Case of Search Engines' (2015) 38 World Competition 349, 358-61. Conversely, Manne and Wright find some evidence for a broader market that includes offline advertising, social media, organic search results and vertical search engines, without however ultimately deciding the question: Manne and Wright, above n 76, 194-203. Florence Thépot makes a powerful argument that social media and online search are mutual competitive constraints: Florence Thépot, 'Market Power in Online Search and Social Networking: A Matter of Two-Sided Markets' (2013) 36 World Competition 195. Regardless of where the line for market definition is drawn, all these forms of advertisements certainly put some competitive constraint on Google's market power and should not be discounted to zero (as the binary market definitions exercise tends to do, unless the remaining competitive constraint is sufficiently taken into account in assessing dominance). The second question is whether Google has a great comparative advantage over its competitors. This is often assumed without more, based on Google's much wider reach. Manne and Wright object that Google as the platform can monetise and internalise these two-sided market effects - a platform with more users will simply have higher advertising prices: Manne and Wright, above n 76, 206-9, 223-6. Theoretically, this seems compelling. Despite Google's excellent informational basis, I doubt, however, that the higher value that advertisers place on reaching more users is completely internalised by Google. Otherwise, advertisers would be completely indifferent between advertising on DuckDuckGo or on Google and this does not seem compatible with anecdotal accounts of advertisers' observed behaviour.

88 Nazzini, above n 1, 304. 
two-sided business models prevail, the two sides must not be viewed in isolation. 89

The decisive question is therefore whether Google is in a position to behave to an appreciable extent independently of its competitors and consumers on the search side. ${ }^{90}$ Prima facie this seems unlikely — not only is a switch to competitors costless in pecuniary terms, but in contrast to the Microsoft browser cases (in the US and the EU), switching does not even require a download. The search bar in most browsers makes it easy to toggle between different search engines. Nevertheless, it is not a priori impossible that: (1) Google has advantages over its competitors that make its position unassailable; or (2) consumers - for rational, irrational or boundedly rational reasons - do not exert the little effort it takes to switch search engines even if the alternatives are better.

\section{Searching for Competitive Constraints on Google}

The first step is to identify the players that put a sufficient competitive constraint on Google by defining the relevant market. Given the two-sided business models of all competitors in the area of web search, the advertising and the search user side have to be examined together. ${ }^{91}$ Constraints on the advertising market will largely follow the constraints on the search side. I will first discuss the general difficulty with applying the small but significant and non-transitory increase in price ('SSNIP')/hypothetical monopolist approach (see below Part IV(2)(a)). I will then examine the competitive constraints on Google originating, among others, from horizontal search engines and vertical search sites and applications (see below Part IV(2)(b)).

\section{(a) SSNIP and SSNDP on the Free Side of a Two-Sided Business Model}

The traditional SSNIP test cannot be applied without modifications on the search side of a market in which most or all participants use a two-sided business

89 James D Ratliff and Daniel L Rubinfeld, 'Is There a Market for Organic Search Engine Results and Can Their Manipulation Give Rise to Antitrust Liability?' (2014) 10 Journal of Competition Law \& Economics 517, 518-19, 521-8, 534-8; Lars Wiethaus, 'Google's Favouring of Own Services: Comments from an Economic Perspective' (2015) 6 Journal of European Competition Law \& Practice 506, 506-8. See generally American Bar Association, 'Two-Sided Markets' in Market Definition in Antitrust: Theory and Case Studies (2012) 437; Monopolkommission [Monopolies Commission], 'Wettbewerbspolitik: Herausforderung digitale Märkte [Competition Policy: The Challenge of Digital Markets]' (Report No 68, June 2015) <http://perma.cc/B63S-6JXX> ('Monopolies Commission Report'). For an English summary, see <http://perma.cc/VRM3-KT9P>. See also Manne and Wright, above $n$ 76, 222. Hoppner advocates the definition of 'separate relevant markets ... for each user group with differing demands', but seems to share the view that the interaction between the various sides has to be considered: Hoppner, above n 87, 352-5.

90 Nazzini, above n 1, 304

91 See Weithaus, above n 89. I speak deliberately of a two-sided business model (rather than a two-sided market), inter alia, because the reciprocal cross-side positive externalities that are required for a narrow definition of two-sided markets are largely absent: Giacomo Luchetta, 'Is the Google Platform a Two-Sided Market?' (2013) 10 Journal of Competition Law \& Economics 185, 191-6. The use of a two-sided business model is a conscious choice, albeit one currently made by all major search service providers, rather than necessitated. 
model where the search user is charged nothing. ${ }^{92} \mathrm{~A}$ five to 10 per cent increase in price from a starting price of zero would still be zero.

There are various ways in which the SSNIP test could be modified. One way would be to conceptualise a SSNIP in absolute instead of relative terms: what if Google started to charge a very small but positive price on the search users' side? Micro-payments are, after all, no longer a hypothetical possibility any more. This would very likely result in a loss of most search users to one of Google's competitors on the general search market (for example Bing, DuckDuckGo or Yahoo!). ${ }^{93}$ While one may dismiss this scenario as an unrealistic turn of events, the thought experiment does indicate that Google's market power is limited.

Another way to reconceptualise the SSNIP test would be to ask what would happen if Google's competitors were to lower their price below zero. ${ }^{94}$ A price below zero may sound unusual, but it is just taking the logic of a two-sided business model to its extreme: if a price of zero is not low enough to attract a sufficient number of search users on that side to make the platform attractive for paying advertisers on the other side, then offering money to search users could help to build up critical mass. This solution, which at first glance looks like a typical musing from the ivory tower, is a realistic possibility. In the US, Bing has been using this strategy since 22 September 2010 in the 'Bing Rewards Program', in which search users earn reward points for using Bing, which can be redeemed for Microsoft or other products or services. ${ }^{95}$ Since the introduction of Bing Rewards, Microsoft's search share has steadily increased from some 11 per cent to nearly 21 per cent in the US. ${ }^{96}$

92 Monopolies Commission Report, above n 89, 159 [469]. The report discussed is in the context of merger control. See also Verhaert, above n 14, 268-9.

93 Kersting and Dworschak, above n 76, 4.

94 This possibility is often (prematurely) discarded a priori. See Monopolies Commission Report, above n 89, 87 [217]; Lianos and Motchenkova, above n 76, 421 n 5. But see Manne and Wright, above n 76, 211 n 138: the authors noted Bing's cashback program. See text following this footnote.

95 For the launch, see Danielle Tiedt, 'Earn Rewards for Searching and Exploring with Bing!' on Microsoft, Bing Blogs (22 September 2010) <http://perma.cc/2NKW-ANMP>. For a description, see, eg, Miranda Miller, The Complete Guide to Bing Rewards (11 January 2015) Business 2 Community <http://perma.cc/YQ5D-BXDE>.

96 The ComScore September 2015 US Desktop Search Engine Rankings report an Explicit Core Search Share of 20.7 per cent for Microsoft sites, compared to 63.9 per cent for Google sites and 12.6 per cent for Yahoo!: ComScore, ComScore Releases September 2015 US Desktop Search Engine Rankings (16 October 2015) <https://perma.cc/ DRN3-CUXX?type=source> ('ComScore 2015 US Desktop Search Engine Rankings'). For Microsoft, this is an increase from 20.2 per cent in April 2015, 20.1 per cent in March 2015 and 19.8 per cent in February 2015: ComScore, ComScore Releases April 2015 US Search Engine Rankings (15 May 2015) <https://perma.cc/5Z5L-UM6V?type=source>; ComScore, ComScore Releases March 2015 US Search Engine Rankings (15 April 2015) <https://perma.cc/L6QM-2DLX?type=source>; ComScore, ComScore Releases February 2015 US Desktop Search Engine Rankings (17 March 2015) <https://perma.cc/ MZK3-RVUP?type=source $>$. In the last full month before the introduction of Bing Rewards (August 2010), Microsoft's search share was 11.1 per cent: ComScore, ComScore Releases August 2010 US Search Engine Rankings (16 September 2010) <https://perma.cc/ 7V9Y-WGQF?type=source $>$. Of course, correlation is not causation and Microsoft's share had also grown prior to Bing Reward's introduction. However, there is anecdotal evidence that Bing Rewards is a relevant factor in the decision to switch. In a computer magazine test report, in listing the reasons for switching to Bing, the Bing Rewards program was listed in the prime position: Mark Hachman, The 4 Reasons I Switched from Google to Bing (22 September 2014) PC World <http://perma.cc/2M42-CR2P>. 
The consumer reaction if Google's competitors were to lower their prices to negative prices (for example, by way of rewards programs) would arguably be more heterogenous than in the case of Google charging positive prices. If Google's competitors introduced rewards programs, it seems likely, as is the case in the US and Canada, that many consumers would continue to use Google while some others would switch, for some or all searches, to earn rewards - just as some consumers in the bricks and mortar world use coupons and others do not. In contrast, as explained above, I would assume that if Google were to charge small but positive prices, most consumers would switch to a competitor who continues to offer at a price of zero. To a rational choice economist, this difference between the reactions to Google raising prices minimally and its competitors lowering prices minimally may seem puzzling, even illogical in the absence of sufficient income effects, but the asymmetric psychological impact of losses and gains is by now well documented. ${ }^{97}$ Additionally, Michal Gal and Daniel Rubinfeld have pointed out that there is a separate 'free effect': there is a larger difference between having to pay one cent instead of nothing than between having to pay two cents instead of one. ${ }^{98}$ This 'free effect' would get lost if Google started to charge even a miniscule positive price but it remains unaffected when Google continues to charge nothing, but its competitors lower their prices below zero.

Yet another way to apply the idea underlying the SSNIP test to markets in which players use two-sided business models is to reconceptualise it as a small but significant non-transitory decrease in quality ('SSNDQ') test. ${ }^{99}$ What would happen if Google decreased its quality a little? Would consumers switch to competitors? It has rightly been pointed out that quality is the dimension on which search engines compete ${ }^{100}$ and so it may appear as if the SSNDQ test would be a good alternative to SSNIP. The application of the SSNDQ test faces its own hurdles, however. The basis of the SSNIP test is that we can conceptualise the perfectly competitive counterfactual: marginal cost. ${ }^{101}$ It is this benchmark from which we hypothesise the small but significant increase in price. In the case of quality, we would have to assume some uniform quality

97 See, eg, Daniel Kahneman, Jack L Knetsch and Richard H Thaler, 'Experimental Tests of the Endowment Effect and the Coase Theorem' (1990) 98 Journal of Political Economy 1325.

98 Michal S Gal and Daniel L Rubinfeld, 'The Hidden Costs of Free Goods: Implications for Antitrust Enforcement' (Working Paper No 14-44, New York University School of Law, January 2015).

99 Raymond Hartman et al proposed the small but significant non-transitory decrease in quality ('SSNDQ') test: Raymond Hartman et al, 'Assessing Market Power in Regimes of Rapid Technological Change’ (1993) 2 Industrial and Corporate Change 317. See also Organisation for Economic Cooperation and Development Competition Committee, 'The Role and Measurement of Quality in Competition Analysis' (Report No DAF/COMP(2013)17, Organisation for Economic Cooperation and Development, 28 October 2013); Ariel Ezrachi and Maurice E Stucke, 'The Curious Case of Competition and Quality’ (2015) 3 (Supp 1) Journal of Antitrust Enforcement 227. In the Google context, Andreas Heinemann has proposed the use of the SSNDQ: Andreas Heinemann, 'Google als kartellrechtliches Problem? [Google’s Antitrust Problem?]' (Report No 213, Zentrum für Europäisches Wirtschaftsrecht [Centre for European Economic Law], 19 January 2015) $<$ http://perma.cc/2S95-TSQL>.

100 Patterson, above n 85, 7-8; Verhaert, above n 14, 270.

101 In order to avoid the 'Cellophane Fallacy'. Cf Commission Notice on the Relevant Market for Purposes of Community Competition Law [1997] OJ C 372/5, 7 [19]. 
across search engines and then ask whether a small but significant decrease in quality would make consumers switch. Patterson has raised the possibility of using a standard of 'unmanipulated results', a standard that may resonate with those arguing for 'search neutrality' and using only 'organic' results, but Patterson himself has rightly dismissed the idea. ${ }^{102}$ His reason is mainly that one would have to rely on the search engine's willingness to admit manipulation. ${ }^{103}$ This in itself may not be a compelling argument: a competition authority could force disclosure of the algorithm and detect manipulation; Benjamin Edelman has attempted to infer 'hard-coded' manipulation from search terms with minor variations; 104 and Michael Luca, Tim Wu and the Yelp Data Science Team in their study ('Luca, Wu and Yelp study') somehow manage to compare Google's actual results with those using Google's organic results. ${ }^{105}$ What makes the 'unmanipulated' algorithm an inappropriate benchmark is more that manipulation vel non is not a good standard for comparative quality from which market power could be inferred: a 'manipulated' excellent algorithm may still produce better results than a weak competitor's simplistic 'organic' algorithm. And then there is the small issue of quantifying quality that would be required to determine whether users would switch if there is a small but significant non-transitory decrease in quality.

\section{(b) Searching for Competitive Constraints from Horizontal and Vertical Search}

So, SSNIP or SSNDQ are only mildly helpful in our context. ${ }^{106}$ However, the objective of market definition is to identify the sources of relevant competitive constraints, and this can be done without these tools. The most direct source of such constraints for Google's general web search are certainly other general web search engines (such as Bing, DuckDuckGo or Yahoo!). The question is largely whether the competitive pressures on Google from vertical search sites and applications should be taken into account.

A significant proportion of searches is done on vertical search sites or apps (such as Amazon, Booking.com, eBay, Expedia, Kayak, TripAdvisor etc) or social networks (especially Facebook) - either instead of using general web search or in addition to it (multi-homing). With increasing use of mobile devices, this proportion of vertical searches is likely to rise.

In a traditional market definition exercise, these latter sources of competitive constraint would, however, likely be excluded as 'not sufficiently interchangeable'. While every search done on a vertical search engine can be done on a general web search engine, it is not possible to do a general search in a vertical search application; substitutability is one-way only. As Louis Kaplow

\footnotetext{
102 Patterson, above n 85, 8.

103 Ibid.

104 Benjamin Edelman, Hard-Coding Bias in Google 'Algorithmic' Search Results (15 November 2010) <http://perma.cc/EC6U-PKC7>. See also Benjamin Edelman, 'Bias in Search Results?: Diagnosis and Response’ (2011) 7 Indian Journal of Law \& Technology 16, 21-4. This article also discusses the pros and cons of other approaches, such as comparing search engine results from different search engines, search results over time and so on.

105 See below n 113

106 See above Part IV(A)(2)(a).
} 
has forcefully argued, the underlying problem is that traditional market definition with its focus on 'interchangeability' looks at cross-elasticity rather than at elasticity of demand. 107

Whatever the merits of market definition may or may not be in the abstract, ${ }^{108}$ a market definition with a binary outcome - a source of competitive constraint is within or outside of the defined market - bears the danger of excessively discounting substantial competitive constraints from sources that fall (just) outside the relevant market. ${ }^{109}$ The market definition in Google seems a prime example: while no vertical search engine in itself is a full substitute for a general web search engine, general web search may lose customers into all directions - queries for products may go to Amazon, eBay or other price comparison websites; queries for travel may go to Booking.com, Expedia, Kayak.com, Opodo and Tripadvisor etc; queries for encyclopaedic knowledge may go directly to Wikipedia; and so on. The competitive pressure on any one general web search services does not exclusively come from the other general web search services, but also in the form of vertical search services from all different directions depending on the nature of the search. These vertical search services, moreover, are particularly important competitive constraints on Google because they skim off the particularly profitable 'transactional' searches - customers searching for products, flights or hotels are looking to spend money; what remains for general web search are largely navigational queries $^{110}$ which cannot be, or hardly are, monetised. ${ }^{111}$ This death by a thousand cuts of general web search is not well captured by the traditional market definition exercise - and this is one of the issues of Kaplow's general critique against market definition. 112

In Google, there are three ways of proceeding (unless one wants to abolish market definition altogether):

- $\quad$ Either one includes vertical search or social media queries into the relevant (broad) product market for ‘web search’; or

107 See Louis Kaplow, 'Why (Ever) Define Markets?' (2010) 124 Harvard Law Review 437, 480-95. See also at 484 (citations omitted):

The elasticity ... captures this aggregate of all demand response channels. A single cross-elasticity, by definition, addresses only one. And a handful allows an assessment of only a few. Even if one accurately identifies that substitute or those two or three that have the largest cross-elasticities, their combined effect is less and often will be substantially (possibly overwhelmingly) less than the total effect.

108 Ibid. See also the controversial discussion in the contributions to the 'Kaplow Special Issue’: Louis Kaplow, 'Market Definition Alchemy’ (2012) 57 Antitrust Bulletin 915-52; Gregory J Werden, 'Why (Ever) Define Markets? An Answer to Professor Kaplow' (2012) 78 Antitrust Law Journal 729. See also Robert Pitofsky’s much earlier contribution: Robert Pitofsky, 'New Definitions of Relevant Market and the Assault on Antitrust' (1990) Columbia Law Review 1805. For an excellent overview and proposal for a 'truce', see David S Evans, 'Lightening Up on Market Definition' in Einer R Elhauge (ed), Research Handbook on the Economics of Antitrust Law (Edward Elgar, 2012) 53.

109 Salinger and Levinson, 'Economics and the FTC's Google Investigation', above n 6, 51.

110 Navigational queries are those where the user intent is to locate a particular known homepage (eg 'UCL' or 'Amazon').

111 For the taxonomy, see, eg, Luchetta, above n 91, 195.

112 See Kaplow, 'Why (Ever) Define Markets?', above n 107. 
- $\quad$ One excludes them in a narrow market definition for 'general web search' but takes the competitive constraints properly into account when assessing dominance, thus largely discounting any significance of the market share figure derived from the narrow market definition; or

- $\quad$ One distinguishes various sub-markets for each search category (travel, shopping etc) in which general web search and the pertinent vertical web search services compete.

Google's critics argue that while vertical search is an emerging competitive danger to Google's horizontal search, it should not be included in the same product market. ${ }^{113}$ They see the parallel in Microsoft's exclusionary conduct towards middleware, where middleware was indeed seen as an emerging threat to Microsoft's dominance in the PC Operating Systems market but not as competing on the same product market. ${ }^{114}$ However, this analogy is faulty. The crucial difference is that in Microsoft, the Court of Appeals explained that

[w]hatever middleware's ultimate potential, the District Court found that consumers could not now abandon their operating systems and switch to middleware in response to a sustained price for Windows above the competitive level

adding that such a development was also not expected for the near future. ${ }^{115}$ The competitive pressure from middleware in Microsoft was indirect - it could lead to portability of applications across operating systems and could therefore undermine the applications barrier to entry in the operating systems market. In contrast, consumers can use vertical search services here and now for many of their queries as a substitute to Google. They can and do, for example, start their search for products on vertical search sites such as Amazon or eBay; they search for flights on Expedia, Kayak or Opodo; and they search for hotels on these sites or on Booking.com or TripAdvisor.

These considerations could counsel for an inclusion of vertical search into the relevant market so that the market would be for 'web search' rather than 'general web search'. However, as mentioned above, I would not be surprised to learn that the Commission's market definition excludes vertical search sites from the relevant product market. And again, this is unobjectionable if, and only if, the substantial competitive pressure from these vertical search sites is then sufficiently taken into account when assessing dominance. In practice, however, too often only lip service is paid to the importance of taking into account the competitive constraints from sources outside the relevant market - the principle is acknowledged, but the market is defined narrowly, market shares are therefore high and these high market shares are then mechanistically taken to indicate dominance. In particular, the indifference between taking competitive constraints into account already at the market definition level or later in the dominance assessment ceases to be justified if the 'AKZO presumption' of dominance above

113 Michael Luca et al, 'Does Google Content Degrade Google Search? Experimental Evidence' (Working Paper No 16-035, Harvard Business School, 2015) 10-11 <http://perma.cc/R23U-ZJTF>.

114 Ibid.

115 Microsoft, 253 F 3d 34, 54 (DC Cir 2001). 
a market share of 50 per cent is mindlessly applied. The $A K Z O$ presumption is not very well defined, either in its prerequisites for application or in its consequences. It is unclear whether a case such as the Google case, where market shares are clearly of hardly any heuristic value because of the two-sided nature of the business model and because of the dynamic nature of the market, is one where the $A K Z O$ presumption does not apply because of 'exceptional circumstances', or whether the $A K Z O$ presumption applies but is rebutted by the evidence. The former interpretation seems correct - the Commission and the Court do not apply the AKZO presumption without an examination of the true constraints on the undertaking in question. ${ }^{116}$

Market definition continues to be a useful heuristic tool, but if it is to serve its purpose of defining the competitive constraints on the firm in question, it must not define away the relevant competitive forces.

\section{B Dominance}

Let us now turn to the assessment of dominance. While the comparison of the Microsoft case to the Google case is often unhelpful, here it may indeed be instructive. In Microsoft, it was not the ' 90 per cent market share' in itself that indicated dominance. ${ }^{117}$ Instead, it was the 'application barrier to entry' that made Microsoft's near-monopoly difficult to challenge: the indirect network effects that led to the virtuous circle resulting from consumers choosing the operating system with the most attractive application programs and programmers being most attracted to writing applications for the operating system with the most consumers. ${ }^{118}$

The case against Google would require a showing of a similar conceptual limitation to the effectiveness of the competitive constraints that Google faces. Maurice Stucke and Ariel Ezrachi have outlined the relevant framework for determining if such limitations exist in Google in great detail. ${ }^{119}$ Taking the Microsoft case as a blueprint, we should ask if there are any effects that make Google's large search share unassailable. There is no question that search engines benefit from economies of scale. ${ }^{120}$ Consumers look for relevant search results; and search results become more relevant when more consumers are searching, among other things, because the search engine 'learns' which search

116 See above nn 76-79.

117 Although this did of course play a role. See Commission Decision of 24.03.2004 relating to a Proceeding under Article 82 of the EC Treaty (Case COMP/C-3/37.792 Microsoft) (Commission of the European Communities, Case No COMP/C-3/37.792, 24 March 2004) 118-20 [429]-[435].

118 Microsoft, 253 F 3d 34, 54-55 (DC Cir 2001); ibid 123-7 [448]-[464].

119 Maurice E Stucke and Ariel Ezrachi, 'When Competition Fails to Optimise Quality: A Look at Search Engines' (Research Paper No 268, University of Tennessee College of Law, May 2015). Kersting and Dworschak fail to consider the efficiencies of scale and scope and the behavioural issues discussed in Maurice Stucke and Ariel Ezrachi's research paper. See generally Kersting and Dworschak, above n 76.

120 Even Google admits this in principle. See FTC Memorandum, above n 46, 16. See also Manne and Wright, above n 76, 211-12. 
results are relevant to the users' intent by observing which results consumers click on ('click data'). ${ }^{121}$

These economies of scale certainly make entry difficult for de novo entry. The relevant question, however, is whether these economies of scale are such a significant obstacle to competitors such as Bing, DuckDuckGo or Yahoo! that they cannot compete with Google on their merits. This depends on the shape of the marginal benefits curve. If marginal benefits from further searches for the quality of search results show diminishing returns - that is, the marginal benefit curve from more searches 'flattens out' - then from a certain point onwards additional searches may not necessarily be a significant advantage to the incumbent or, conversely, an obstacle to further expansion of its competitors. ${ }^{122}$ We know from statistics that increasing sample size has diminishing returns and the prediction what search results will be considered relevant is a statistical exercise. ${ }^{123}$

The contentious question is whether Google's competitors have already reached the minimum efficient scale, or whether Google's advantage in terms of search share still provides it with such a substantial competitive head start that

121 FTC Memorandum, above n 46, 14; Stucke and Ezrachi, 'When Competition Fails to Optimise Quality', above n 119, 9-13; Maurice E Stucke, 'Behavioral Antitrust and Monopolization’ (2012) 8 Journal of Competition Law \& Economics 545, 556-9. An excellent description of the workings of search engines is contained in: Salinger and Levinson, 'Economics and the FTC's Google Investigation', above n 6, 33-42. Kersting and Dworschak's assertion that no user is going to choose or keep using Google as a search engine because many other consumers use it is therefore myopic: Kersting and Dworschak, above $n$ 76, 5 .

122 For an attempt to estimate the marginal benefits curve in machine learning generally, see Enric Junqué de Fortuny, David Martens and Foster Provost, 'Predictive Modeling with Big Data: Is Bigger Really Better?’ (2013) 1 Big Data 215, 215-26. Using a Naive Bayes model to predict characteristics from a sparse fine-grained dataset, such as gender from the choice of movies rated, they find increasing absolute benefits even at relatively large volumes of data, but they also find decreasing marginal returns. When looking at their data, it looks (very roughly) as if the curves start to flatten out at approximately 212 to 220 observations (ie between approximately 16000 and 1 million observations). Before one draws the conclusion that for tail queries these numbers (or at least the higher of them) will be difficult to meet for small search engines, one should bear in mind that search engines do not necessarily need to make the very indirect inferences that were the subject of the study. Where the search engine only needs to predict which link users prefer based on which link the users click on, the inference is much less indirect and so considerably fewer observations will likely suffice. Also, for most searches (basically all those searches that are not on current events), it is not the number of searches on a particular day that is relevant for improving the search results, but the number of searches accumulated over days, weeks, months or years.

123 Ibid 219 (citations omitted). As Enric Junqué de Fortuny, David Martens and Foster Provost put it:

The marginal increase in generalization accuracy decreases with more data for several reasons. First, there simply is a maximum possible predictive performance (the 'Bayes rate') due to the inherent randomness in the data and the fact that accuracy can never be better than perfect. Second, modeling (especially linear modeling) tends to find the larger generalities first; modeling with larger datasets usually helps to work out nuances, 'small disjuncts,' and other nonlinearities that are difficult or impossible to capture from smaller datasets. 
competitors have little chance of catching up. ${ }^{124}$ The inquiry has to distinguish between popular searches and so-called (long) tail searches ${ }^{125}$ - that is, rare queries, for example, because they concern very specialised, idiosyncratic or novel questions.

It seems unlikely that the main general search engine competitors have a significant disadvantage vis-à-vis Google. Bing itself claims that, in a head-to-head blind comparison of the organic results of the Bing and Google search engine in the UK, it fares not only as well as, but even better than Google. ${ }^{126}$ Similarly, test results in computer magazines as far back as 2012 report that the qualities of search results from the two main contenders Bing and Google are roughly equivalent. ${ }^{127}$ This seems to suggest that at least Bing has overcome the minimum efficient scale for both popular and tail searches.

Smaller competitors, such as DuckDuckGo, appear to do well at least in popular searches, but may perform slightly worse in tail searches. Despite this conceivable disadvantage, the number of DuckDuckGo searches has increased exponentially over the last years. The search engine that launched in 2008 reached one million searches per day on 13 February $2012(\Delta \mathrm{t} / 1$ million $\approx 42$ months); two million on 10 June 2013 ( $\Delta \mathrm{t} / 1$ million $\approx 16$ months); three million on 17 June $2013(\Delta \mathrm{t} / 1$ milion $\approx 0.25$ months $)$; four million on 19 August 2013 $(\Delta \mathrm{t} / 1$ million $\approx 2$ months $)$; five million on 26 February $2014(\Delta \mathrm{t} / 1$ million $\approx 1.2$ months); nine million on 23 March 2015 ( $\Delta \mathrm{t} / 1$ million $\approx 3.25$ months); and 10 million on 22 June 2015 ( $\Delta \mathrm{t} / 1$ million $\approx 3$ months $).{ }^{128}$ Of course, these numbers pale beside the approximately 11.2 billion explicit core searches on Google sites in the month of June 2015 on US desktops alone (that is, some 373 million explicit core searches per day). ${ }^{129}$ However, DuckDuckGo's rapid increase in

124 See FTC Memorandum, above n 46, 16-18. Manne and Wright claim, based on 'conversations ... with industry insiders' that 'algorithmic results are only weakly affected by the number of end users or searches' and that there is a 'rapidly diminishing marginal return to incorporating more searches': Manne and Wright, above n 76, 212. Similarly, they claim that the minimum viable scale is 'likely quite small': at 236. This assertion sits uncomfortably with their otherwise strict demands for empirical evidence. For example, they describe as 'troubling' the approach of authors who had claimed that there are barriers to entry and substantial marginal benefits to incorporating further searches: at 225, 212 n 139. See also at 207: 'Much more and better empirical analysis should be brought to bear'. Stucke and Ezrachi point to Microsoft's claims of substantial efficiencies of scale justifying the Microsoft/Yahoo! agreement: Stucke and Ezrachi, 'When Competition Fails to Optimise Quality', above n 119, 11-12, 22-7. Robert Bork and J Gregory Sidak argue that economies of scale arguments are overblown and quote Microsoft's Chief Executive Officer Steve Ballmer's prediction that Microsoft 'will beat Google in all markets': Robert H Bork and J Gregory Sidak 'What Does the Chicago School Teach about Internet Search and the Antitrust Treatment of Google?' (2012) 8 Journal of Competition Law \& Economics 663, 689, quoting Sunny Sen and Josey Puliyenthuruthel, 'Microsoft Will Beat Google in All Markets: Steve Ballmer', India Today (online), 6 June 2012 <http://perma.cc/2ZU8-927B>.

125 FTC Memorandum, above n 46, 14; Stucke and Ezrachi, 'When Competition Fails to Optimise Quality', above n 119, 23.

126 Microsoft, Bing It On: Bing vs Google <http://perma.cc/9PGM-98U9>; The Bing Team, 'Going Head-to-Head - And Why Online Searching Has Changed Forever' on Microsoft, Bing Blogs (29 April 2014) <http://perma.cc/Y5AS-TWNA>. The results of the study are said to be significant at the five per cent level. The methodology seems to have favoured popular searches, so that the result would not necessarily be the same for tail searches.

127 See, eg, Liane Cassavoy, Bing versus Google: Search Engine Showdown, PC World $<$ http://perma.cc/M23F-YLC7>; Hachman, above n 96.

128 DuckDuckGo, About Us <https://perma.cc/S6R4-ERZJ>.

129 ComScore 2015 US Desktop Search Engine Rankings, above n 96. 
popularity would seem to indicate that DuckDuckGo with its single digit (or recently low double digit) million searches is at least near the minimum efficient scale for producing good quality search results. Whether one can make this inference also for long tail searches depends on how many DuckDuckGo users multi-home. Nevertheless, DuckDuckGo's success, despite its small search user base, makes it somewhat unlikely that Microsoft's Bing and Yahoo! (approximately 3.55 billion and 2.2 billion explicit core searches on US desktops in June 2015 respectively) ${ }^{130}$ would have insurmountable disadvantages due to economies of scale compared to Google. Data on user intent that Google collects in one hour would be collected in some four to five hours by these competitors. For searches other than searches for current events, this is hardly an obstacle; and for current events, search engines have other sources of information (what is trending on Twitter, for example). Overall, then, the 'economies of scale' barrier to entry may be very real for de novo entry, but Google's competitors seem to be well beyond the minimum efficient scale.

Two additional effects are at play. First, most search engines, except for DuckDuckGo, learn about user intent not only from other search users' searches, but also from the individual user's previous searches. ${ }^{131}$ The search intent of most antitrust lawyers when searching for 'hardcore' likely differs from that of most generic search users. Search users who multi-home or try switching to another search engine may consider the alternative search engine's results inferior simply because that search engine has not yet had the chance to learn what this particular user means with a given search query. ${ }^{132}$

Secondly, Google may have an additional advantage in what Stucke and Ezrachi call 'scope of data'. 133 The widespread use of services such as Gmail and YouTube gives Google an additional advantage in determining its search users' intent when they use the search engine while being logged into these other services. Again, however, Google’s gradual erosion of market share and Bing's and Yahoo's growing market shares (at least in the US, ${ }^{134}$ Germany ${ }^{135}$ and the

130 Ibid.

131 Argenton and Prüfer, above n 83, 76. Here, the authors argued for a requirement to share context-dependent user data.

132 Stucke and Ezrachi, 'When Competition Fails to Optimise Quality’, above n 119, 31-2.

133 Ibid 13-14. See also Körber, ‘Common Errors Regarding Search Engine Regulation', above n 15, 241. Torsten Körber sees such 'personalisation' as a potential source of switching cost in the future.

134 See StatCounter GlobalStats, Top 5 Desktop, Tablet \& Console Search Engines in the United States from July 2008 to Oct 2015 <https://perma.cc/M7CY-9PVJ?type=source>; above n 96 and accompanying text. See also StatCounter, Yahoo Achieves Highest US Search Share Since 2009 (7 January 2015) <http://perma.cc/BZ45-9J8K>. It notes that 'Google fell to the lowest monthly share yet recorded by [StatCounter]'. Recordings by StatCounter started in July 2008. See also StatCounter, Yahoo's Growth Stalls in February but Earlier Gains Largely Retained (2 March 2015) <http://perma.cc/Y2RR-U7PG>.

135 StatCounter GlobalStats, Top 5 Desktop, Tablet \& Console Search Engines in Germany from July 2008 to Oct 2015 <https://perma.cc/4X5G-2SX8?type=source>; Monopolies Commission Report, above n 89, 81 [192], 83 [Figure 5.1]. 
UK) ${ }^{136}$ and the good results of Bing in comparisons of search result relevance in tests in Europe would seem to indicate that this advantage is not an insurmountable obstacle to quality improvements for search engines that cannot rely on these additional streams of information.

These qualitative considerations seem to indicate that Google's advantages over its closest competitors owed to economies of scale and scope exist but are likely modest. Without empirical evidence, it is impossible to determine if these factors genuinely limit the effectiveness of a competitor that is (but for the economies of scale) as efficient as Google. ${ }^{137}$ Quantitative evidence as to switching behaviour by users in the presence of external shocks would be helpful. Good data on how many consumers in Europe multi-home at least part of their searches would also help to assess Google's degree of independence. ${ }^{138}$

And yet, something is wrong in this picture. If Bing is qualitatively comparable to Google (as claimed by Bing itself), and the price of both is zero for the search user, why does Google have a search share of some 90 per cent?

The answer is arguably twofold. First, if switching is costless, even minor perceived differences in quality may lead the majority of users to switch. Secondly, Google arguably benefits from the stickiness of defaults (or, as Stucke and Ezrachi call it, 'status quo bias'). ${ }^{139}$ Many consumers use whatever is provided by default, unless the default option exceeds a certain pain threshold. ${ }^{140}$ Google has been the default search engine in many browsers, and the search

136 StatCounter GlobalStats, Top 5 Desktop, Tablet \& Console Search Engines in United Kingdom from July 2008 to Oct 2015 <https://perma.cc/RY6M-NSLA?type=source>. The data from StatCounter from January 2010 to September 2015 for the UK indicate that the slope of the regression line for Google is negative (with a slope of approximately -0.074), while it is positive for Bing $(+0.06)$ and Yahoo $(+0.023)$ (parameters used: UK, Search Engine, Desktop/Tablet/Console, January 2010 to September 2015). To illustrate this development, Google’s average search share decreased from 92.44 per cent over the first 12 months in this period to 88.53 per cent in the last 12 months in this period. In the same periods, Bing's average share rose from 3.47 per cent to 6.72 per cent and Yahoo!'s share rose from 2.54 per cent to 3.62 per cent.

137 For different assessments of the persuasiveness of tipping the search market, see Argenton and Prüfer, above n 83; Suiyi Zhang, 'How Have Network Effects Affected the European Commission's Enforcement of Competition Law in Technology Enabled Markets?' (2015) 36(2) European Competition Law Review 82.

138 For the US, it is reported that more than 70 per cent of heavy internet search users multi-homed on at least three search engines within a month: Daniel A Crane, 'Search Neutrality and Referral Dominance' (2012) 8 Journal of Competition Law \& Economics 459, 463, citing Jacqui Cheng, Nielson: Fickle Search Engine Users Could Benefit Bing (2 June 2009) Ars Technica <http://perma.cc/Q7ZZ-TZCX>. See also Bork and Sidak, above n 124, 671-2.

139 Stucke and Ezrachi, 'When Competition Fails to Optimise Quality', above n 119, 35-9; Stucke, 'Behavioral Antitrust and Monopolization', above n 121, 556, 564-6. I prefer to speak of the stickiness of default because 'status quo bias' indicates a bounded rationality explanation; while this arguably accounts for a large part of the stickiness, in some cases it could just be that the expected transaction costs (not of making two mouse clicks, but of learning which two clicks to make) are higher than the expected benefit from switching.

140 For example, the 'blinking twelve' phenomenon in the 1980s. See Paul M Schwartz, 'Beyond Lessig's Code for Internet Privacy: Cyberspace Filters, Privacy Control, and Fair Information Practices’ (2000) Wisconsin Law Review 743, 754-5, citing Neal Stephenson, 'In the Beginning Was ... the Command Line' (Avon Books, 1999) 67. When Apple introduced Apple Maps as a default with its iOS, the pain threshold was apparently reached and Apple, under consumer pressure, reverted to Google Maps as a default. 
function on many websites is 'powered by Google'. ${ }^{141}$ The fact that 'to google' has turned into a verb may have helped the stickiness of this default. 'Bing it' does not sound quite right, and 'googling with Bing' only works in a comedy context. ${ }^{142}$ Google has used to its advantage what Coca-Cola has been avoiding for decades: becoming a generic term.

Some may, again in analogy to the Microsoft case, consider the stickiness of defaults to be a factor cementing Google's search shares and therefore providing it with a degree of independence from its competitors - in short, a factor in favour of finding dominance. ${ }^{143}$ And I agree that the stickiness of the default has a large part to play in the current prevalence of Google, especially because consumers may have difficulties in detecting the relative quality of search engines. ${ }^{144}$

However, in contrast to the Microsoft case, in which the stickiness of the default browser or media player favoured Microsoft's pre-installed version, in the Google case, stickiness is not a factor that cuts only one way. On the contrary, stickiness is a major reason why Google's large search shares today may not mean much tomorrow if it does not keep innovating. Stucke and Ezrachi point to Yahoo!'s jump in search shares when Firefox switched the default search engine to Yahoo! to illustrate the stickiness of defaults: among Firefox users, the proportion of Yahoo! searches increased from 9.9 per cent to 28.3 per cent, ${ }^{145}$ and overall the search share rose from 8.6 per cent in November 2014 to 10.9 per cent in January 2015 in the US. ${ }^{146}$ This shows how quickly Google's large market shares could disappear if browsers - or applications on mobile phones - used a different search engine as the default. Stucke and Ezrachi rightly point out that 'the battle for search may be the battle for the dominant browser and operating system, especially on mobile phones, where search is increasingly occurring'.147 Accordingly, Google's share of searches is very fragile, although it is true that Google's successful forays into the browser and mobile phone operating systems markets are clearly aimed at protecting this share.

\section{Dominance: Conclusion}

So, despite the '90 per cent search share' mantra, I am not convinced that Google is dominant even on the market for horizontal web search (and even less on the broader online search market).

First, Google's 90 per cent search share could arguably be reduced if Bing went to negative pricing in Europe as it did in the US and Canada (in the form of

141 In the US, about 65 per cent of organic searches are powered by Google and about 32 per cent by Bing: ComScore 2015 US Desktop Search Engine Rankings, above n 96.

142 Googling with Bing (Directed by CollegeHumor, 2009) <https://www.youtube.com/watch? $\mathrm{v}=\mathrm{tYVCk10AzS0}>$. 'Duck it' for searching on DuckDuckGo may present its own problems.

143 This appears to be the thrust in: Stucke and Ezrachi, 'When Competition Fails to Optimise Quality', above n 119, 36-9.

144 For these problems, see, eg, Patterson, above n 85, 11-14.

145 Monopolies Commission Report, above n 89, 86-7 [214].

146 Stucke and Ezrachi, 'When Competition Fails to Optimise Quality’, above n 119, 36.

147 Ibid 38-9. 
Bing Rewards). ${ }^{148}$ Cynics could even suspect that Microsoft did not introduce Bing Rewards in Europe so as not to undermine its arguments before the Commission - lobbying for antitrust intervention may just be cheaper than competing by offering rewards. It is noteworthy that Bing Rewards in North America and the antitrust case in Europe both started in 2010.

Secondly, and more importantly, competing against Google would be possible by convincing browser or mobile phone applications programmers to use an alternative search engine as a default. Such a change in default would itself be 'sticky', and any 'switchbacks' to Google would be an indication of choice - although this choice could be influenced by a misperception where the new search engine has not yet had time to learn the individual user's search intent; whether that is the case is an empirical question. ${ }^{149}$ The introduction of parallel search options in the browser search bar, for example, in Firefox (offering search on Amazon, Bing, DuckDuckGo, eBay, Google, Twitter, Wikipedia and Yahoo!) or Safari (offering Bing, Google and Yahoo!) is already a step in this direction, a step that could push more consumers to switch to alternative search engines or at least multi-home. Additionally, Apple's explorations into the search sector, with Applebot already crawling the web for use in Siri and Spotlight, could change the competitive search landscape overnight because of Apple's wide distribution, especially in the mobile device sector.

Thirdly, even if vertical search services are not included in the relevant market, not even Yelp denies that vertical search is seriously challenging Google's position and that vertical search will increase with rising numbers of mobile searches. The diversion of searches to vertical search has to be taken into account whether or not it is included in the same market as horizontal search.

All these options to compete make Google's search engine alleged 'quasi-monopoly' much easier to undermine than was the case, for example, with the PC Operating System in Microsoft. Google is not the new Microsoft. Rather it looks as if Google is Microsoft without the factors that led to the dominance finding in Microsoft.

Only if the Commission had solid evidence to demonstrate that there are such efficiencies of scale over and above the high absolute number of searches that Bing and Yahoo! already attract, or such efficiencies of scope that these competitors cannot realistically close the gap, would it become somewhat more likely that a case for Google's dominance could be made. If that were the case, it would be more difficult for competing search engines to convince consumers to switch or to convince browser or application programmers to include an inferior search engine as the default. Until now, however, I have not seen this evidence.

148 Nor can it be argued that this is a barrier to entry that Google did not have to overcome. Yes, Google may have had a 'nearly first' mover advantage (after succeeding against earlier market leaders such as Yahoo!), but in terms of incentivising innovation it would hardly be a good idea to penalise this advantage unless it makes the market position truly unassailable.

149 For example, when Apple introduced Apple Maps as the default with its iOS instead of Google Maps, consumers overwhelmingly switched back to Google Maps. It is unclear, however, to what extent the evident quality deficiencies of Apple Maps could have been removed if consumers had given it more time to learn. 


\section{Abuse}

Even if Google turned out to be dominant not only in a populist, but also in a rigorous antitrust sense, it would have to be shown that Google's giving more prominence to search results of its own vertical search services, specifically Google Shopping, and degrading the ranking of the services of its vertical search competitors (for example, Amazon, eBay, Foundem and Guenstiger.de etc), ${ }^{150}$ constitutes an 'abuse'.

The concept of abuse is not well defined in the abstract. The overarching concept of abuse refers to:

Conduct of a dominant undertaking that, through recourse to methods different from those governing normal competition on the basis of the performance of commercial operators, has the effect, to the detriment of consumers, of hindering the maintenance of the degree of competition existing in the market or the growth of that competition. ${ }^{151}$

But what are the 'methods ... governing normal competition' in the search market? Determining the ranking of search results is the very service provided by Google. One has to be careful in delimiting what the standard of normal competition prescribes unless one thinks that ranking decisions should be micromanaged by competition authorities. ${ }^{152}$ In particular, there is no antitrust duty to provide the 'best' results - whatever this would mean. The argument would have to be along the lines that Google has to apply its organic search algorithm generally without any modifications to its own services as well: a non-discrimination standard. ${ }^{153}$ Yet nobody would deny that Google may show paid advertisements - otherwise the two-sidedness of the business-model would break down - or that it may modify the results derived from the organic search algorithm where a publisher's creative search engine optimisation ('SEO') attempts to fool the algorithm and propel less relevant results to the top. ${ }^{154}$

150 Complainants in the Google case dispute that Amazon and eBay are properly included here because they are merchant sites rather than price comparison sites. See the response to Google's blog post 'The Search for Harm' by Foundem and iComp: Foundem, An Analysis of Google's Public Response to the EC's Formal Charges (10 June 2015) Search Neutrality $<$ http://perma.cc/AC66-Y4HN>; Admin, 'Questions Raised by Google's Response to the Statement of Objections' on iComp (20 April 2015) <http://perma.cc/QH4C-PUJA>. For Google's original blog post, see Amit Singhal, 'The Search for Harm’ on Google, Google Official Blog (15 April 2015) <https://perma.cc/534U-M3QC?type=source>. It appears that the Commission's Statement of Objections has taken this position as well. See Walker, above n 19: '[W]e show why the SO is incorrect in failing to consider the impact of major shopping services like Amazon and eBay'. I lack the empirical data to determine whether Amazon and eBay fall into a properly defined downstream market, but from a demand-side perspective, I would have thought that Amazon's and eBay's market places are good and frequently used functional substitutes for finding competitive prices for products. This intuition would seem to be supported by the fact that the search bar in Firefox lists Amazon and eBay as alternatives (next to Bing and DuckDuckGo). Similarly, see Torsten Körber, 'The Commission’s “Next Big Thing”?’ [2015] Neue Zeitschrift für Kartellrecht 415, 417.

151 This is the rephrasing of the Hoffmann-La Roche formula as used, for example, in Post Danmark A/S v Konkurrencerådet: Post Danmark A/S v Konkurrencerådet (Court of Justice of the European Communities, C-209/10, 27 March 2012) 5 [24].

152 See Crane, above n 138, 466-8; Bork and Sidak, above n 124, 684-7; Körber, 'Common Errors regarding Search Engine Regulation', above n 15, 242-4.

153 This is Michael Luca, Tim Wu and the Yelp Data Science Team's underlying thesis: Luca et al, above n 113.

154 Salinger and Levinson, ‘Economics and the FTC’s Google Investigation’, above n 6, 48-9. 
But if Google may show paid advertisements from third parties, it is difficult to argue that it may not place its own vertical search results in the place in which paid advertisements would be; in that case, it is forgoing the revenue it could get from selling more advertisements and is so paying the price for the advertisement as an opportunity cost. ${ }^{155}$

Exclusionary theories of harm argue that Google leverages its (alleged) dominance on the horizontal search market to vertical search. Demoting search results linking to a competitor's site to a place lower down on the SERP disadvantages competitors, because it is clear that click-through rates decrease very quickly with lower page rank, especially on mobile devices. ${ }^{156}$

There is no room here to go into the debate about the legal qualification of these leveraging claims. ${ }^{157}$ Abstracting from the legal niceties of the various theories of harm, there are two fundamental questions.

The first is the extent of Google's dominance with regard to web search - this has been discussed above. The degree of dominance is important not only for the (binary) question of dominance, but also for the question of abuse, because the notion of abuse is on a sliding scale: the more precarious the dominant position, the clearer the abuse should have to be.

The second issue is the degree of 'exclusion' that is required to amount to an antitrust violation. Even if there should be dominance with regard to web search, and even if Google should be found to demote vertical search results, the degree of exclusion that Google could achieve by demoting results (and the corresponding consumer harm) would be limited because vertical search services receive traffic not only via search engine result pages: users also go directly to their webpages or apps, or are navigated there via third parties' sites. ${ }^{158}$

Furthermore, there is no outright exclusion of Google's vertical search competitors from the search engine result page. However, it may well be that some traffic that would have gone to the vertical search competitors is diverted

155 Ratliff and Rubinfeld, 'Is There a Market for Organic Search Engine Results', above n 89, 525-6.

156 It is arguably true that this is not due to consumers blindly clicking on the first results. See Bork and Sidak, above $n$ 124, 680. In relation to the behaviour of the subjects in Michael Luca, Tim Wu and the Yelp Data Science Team's study, see also below Part V. Therefore, pushing a link further down the page may not have as dramatic consequences as complainants in Google make it out to be. Nevertheless, it is plausible that click-through rates decrease at some point and it is also plausible that they decrease more quickly on the smaller screens of mobile devices.

157 For a discussion, see, eg, Bo Vesterdorf, 'Theories of Self-Preferencing and Duty to Deal — Two Sides of the Same Coin?' (2015) 1(1) Competition Law \& Policy Debate 4. Bo Vesterdorf argues that only refusal to supply is a conceivable theory of harm and that the restrictive Bronner criteria apply. For a discussion and similarly requiring indispensability and elimination of all effective competition, see Nazzini, above $n 1,307-10$. See also Renda, above n 3, 32-40. On the other side of the debate, Nicolas Petit discusses other forms of conceivable abuses and disputes the strictness of the Bronner criteria: Nicolas Petit, 'Theories of Self-Preferencing under Article 102 TFEU: A Reply to Bo Vesterdorf' (Paper, University of Liege - School of Law, 29 April 2015). Ioannis Lianos and Evgenia Motchenkova discuss various theories of harm and EU precedent in detail. See Lianos and Motchenkova, above n 76, 433-43.

158 Daniel Crane questions that Google has 'referral dominance': Crane, above n 138, 463-6. Similarly, see Bork and Sidak, above n 124, 669-71; Körber, 'Common Errors regarding Search Engine Regulation', above n 15, 241-2. 
to other destinations if links to competitors are pushed further down the search engine result page. Does this amount to a constructive refusal to deal?

Similarly, there is no contractual or technological coercion of consumers to choose results higher up on the search engine result page. However, as an empirical matter, it is clear that consumers overwhelmingly choose results near the top of the list. Is this enough for a tying claim?

These are not rhetorical questions. There is evidence that nudging in many contexts works nearly as effectively as coercive regulation, ${ }^{159}$ and there is little reason to suspect that nudging from a private corporation that closely monitors consumer behaviour should be any less effective. Quite the contrary - except, perhaps, that Google was not very successful with nudging consumers into its own social network; Google+ was, after all, not an unqualified success. ${ }^{160}$ The question is what threshold we should use for antitrust intervention. Should antitrust law always intervene when (for the sake of the argument: dominant) undertakings nudge consumers to make less than perfectly efficient choices for themselves - or should we leave the choice to consumers, even if they exercise this freedom of choice imperfectly?

Some might argue that the relevant question should be to what extent the nudging results in consumer harm compared to a hypothetical consumer welfare maximum. The more space Google uses for its proprietary content (universal search results), the further down its competitors' results are pushed on the search engine result page. This, in turn, means that the probability of click-throughs is dramatically reduced. If consumers prefer these alternative results, as the Luca, $\mathrm{Wu}$ and Yelp study appears to show, then the less prominent placement of the competitors' results lowers consumer welfare below a hypothetical maximum. ${ }^{161}$

What is Google's scope for quality degradation? The first question is whether Google has any incentives to provide consumers with 'less relevant' information than it could. Google argues that this is not the case: it claims it would prefer the long-term gain in the form of a greater search user base and the associated higher revenue from advertisers, which is achieved by presenting the most relevant results. ${ }^{162}$ Google's critics claim that Google's actions show that it seeks a different form of long-term gain by excluding vertical search engines as nascent threats to the general search paradigm. ${ }^{163}$ Who is right?

Both have a point, and neither tells the full story. There is a trade-off between the long-term gains to be made from increased appeal to consumers by including the most relevant results, and the short-term benefits from immediate monetisation as well as the even longer-term gain that could potentially be made

159 Cass R Sunstein and Richard H Thaler, 'Libertarian Paternalism Is Not an Oxymoron' (2003) 70 University of Chicago Law Review 1159; Richard H Thaler and Cass R Sunstein, Nudge: Improving Decisions about Health, Wealth, and Happiness (Penguin Books, revised ed, 2009).

160 An example mentioned by Daniel Zimmer: Daniel Zimmer, 'Google zerschlagen? [Divestiture in Google?]' (2014) 10 Wirtschaft und Wettbewerb 923 <http://perma.cc/ NM7K-HHG3>.

161 Luca et al, above n 113.

162 See, eg, Michael A Salinger and Robert J Levinson, 'The Role for Economic Analysis in the FTC's Google Investigation' (Paper presented at the Fourth Annual Conference on Internet Search and Innovation, Northwestern University School of Law, Chicago, June 2013) 27 n 45.

163 Luca et al, above n 113, 10-11. 
from excluding more relevant search results from competitors and preventing a paradigm shift in favour of vertical search engines. Depending on Google's discount rate and the relative amounts of the three types of expected gains, this trade-off could give Google, in some circumstances, an incentive for quality degradation, especially if consumers do not sufficiently realise the degradation. ${ }^{164}$ And yet, the more significant the degradation, the more likely it is that consumers notice, and if not consumers, then information intermediaries, such as computer magazines, perhaps prompted by competitors' complaints. In other words, the more substantial the consumer harm would be if the nudging were effective, the less effective the nudging is likely to be.

It seems to me that there are two possibilities: either Google primarily aims to provide good search results to maximise the 'virtuous circle' from attracting more search users and thereby attracting more advertising (in this scenario of limited quality degradation, the mild nudging towards Google services would be effective but any consumer harm would be limited); or Google degrades quality substantially, in which case consumer harm could be substantial if nudging were effective, but it should be much easier for consumers to notice, or competitors to draw consumers' attention to better alternatives, so that nudging is unlikely to be effective. In neither scenario would we face a substantial competition law issue.

However, it should be noted that this is essentially the flip side to my scepticism as to Google's market power. ${ }^{165}$ Provided evidence exists that shows that Google really does have substantial market power, this would at the same time show that Google is sufficiently independent to degrade substantially without consumers switching.

It is important to note that it is not enough to show that Google has some leeway to degrade quality. This possibility clearly exists, especially because Google remains an unavoidable trading partner for advertisers as long as most consumers use Google, even if some switching occurs. This advantage, however, is what we usually see in monopolistic competition with differentiated products - there is some degree of independence, but it is limited by the switching of marginal consumers. ${ }^{166}$ The question is whether Google is 'to an appreciable extent' independent, that is, could significantly degrade quality before a sufficient proportion of consumers switches - and here I have my doubts.

It should be noted that the quality degradation point is not only or even primarily relevant as an exploitative abuse on the consumer side. Because of the two-sided business model, it is also relevant for any exploitative abuse issues on the advertising side and — most importantly — for any exclusionary theories of harm vis-à-vis vertical search engines.

Lowering the antitrust intervention trigger from a threshold of contractual or technological coercion to a 'behavioural nudging' threshold whenever consumer welfare falls below a certain threshold would have implications far beyond the

164 For an analysis (from a pro-Google perspective), see Ratliff and Rubinfeld, 'Is There a Market for Organic Search Engine Results', above n 89, 528-33.

165 For the close relationship between the dominance and abuse enquiry in Google, see Patterson, above $n$ 85, 8, 18.

166 Since the free entry and exit condition is not fulfilled, this is not technically monopolistic competition. 
Google case. ${ }^{167}$ For example, consumers regularly buy branded products even where the product in question is completely homogenous (let us say: table salt) and branded products are more expensive. This preference for brands is largely due to brand loyalty inducing commercials. This overspending on branded products could also be considered to be a loss of consumer welfare measured against an ideal standard, and in the aggregate probably adds up to quite a substantial loss in consumer welfare. And yet, even if any particular brand is dominant, we do not prohibit commercials. We generally do not force consumers to choose what would be objectively the most efficient way of living, even if this inevitably has the effect of depriving competitors which offer more efficient solutions of customers. Preferences are subjective and we generally do not inquire into the rationality or irrationality of the process in which these preferences are formed. The lowering of the standard from a prohibition of coercion to a prohibition of nudging also has implications for the potential remedy in the Google case. Right now, Google appears to self-preference its proprietary services not by SEO as others do because it can affect the search page ranking directly. If Google were ordered to rank its proprietary services under its organic search algorithm, it would have to employ SEO. However, Google would then be in charge of determining the organic search algorithm and SEO for its proprietary services. Having perfect knowledge of the organic search algorithm would allow perfect SEO, which would likely have very similar effects on the relative search rankings as the current system. The only way around this would arguably be a Chinese Wall between the search algorithm and the proprietary services divisions within Google.

\section{CONCLUSION}

The EU has jurisdiction to prescribe in the Google case, regardless of whether the effects doctrine or the implementation test is preferred. In terms of procedure, the Commission had little choice but to move from the commitment negotiations to a Statement of Objections after the negotiations had become politicised. A commitment decision without an articulated theory of harm would have seriously damaged the Commission's credibility in antitrust matters. Allegations of European protectionism are understandable, given the grandstanding of politicians, but they are ill-founded if levelled against the Commission's antitrust infringement procedure.

The multiplication of investigations as a consequence of the proliferation of competition law regimes, the globalisation of trade and the application of the effects doctrine or implementation test leads to a bias towards over-enforcement, because it is the strictest regime that prevails. This counsels caution in borderline cases - and Google is a borderline case.

The substance of the Google case is impossible to assess without empirical evidence. One can certainly develop a story of harm. Google may be dominant: it commands a high share of searches, making it an unavoidable trading partner for advertisers. Competitors may be unable to compete on the merits based on Google's superior economies of scale and scope, as well as on the basis of the

167 For a related discussion in the context of Google’s dominance, see Nazzini, above n 1 , 306-7. 
stickiness of Google as a default search engine. Google may abuse its dominant position by self-preferencing: while not excluding competing vertical search results outright, it demotes them to positions on the search page where fewer consumers click on them, perhaps amounting to a constructive refusal to deal; or by tying its proprietary vertical search results to the general web search through 'behavioural nudging'.

The possibility of telling such as story, however, does not mean that it reflects reality. Whether it does is an empirical question. Prima facie, it seems to me more likely that Google's position in the web search market is much more fragile. Google already has formidable competitors on the general web search market: Apple seems on the verge of joining the fray, which could quickly upend the competitive landscape, especially in mobile search; vertical search sites, social networks and applications on mobile devices constrain Google's ability to push any proprietary inferior services lest they lose customers and their trust; the very stickiness of defaults that currently favours Google could turn against it when browsers, social media sites, voice-activated digital assistants such as Siri or Cortana or mobile device manufacturers switch to a different web search engine default. It seems to me that all these factors make Google's position much more precarious than the position of Microsoft in its antitrust cases that are often invoked as being a parallel to Google.

With regard to Google's abuse, I am likewise not convinced so far. I can see that behavioural nudging can have effects, and that Google uses these effects to its advantage. This does not mean, however, that we should lower the threshold for antitrust intervention from 'coercion' to any 'behavioural nudging'. At an absolute minimum, it would have to be shown that consumers do not react to substantial quality degradations. The Luca, Wu and Yelp study shows that consumers are not hardwired to click on the first search results regardless of relevance. If the first results appear less relevant, consumers look further down the page. If Google were to force consumers consistently to look further down the page, this would increase in consumer search costs, providing an opening for competitors to offer a better alternative.

Moving from a coercion standard to a behavioural nudging standard would have profound implications beyond the Google case. Competition law is generally seen as an empowerment of consumers: competition forces producers to conform to consumer preferences. Competition law only intervenes where 'normal competition' is impaired because consumers are coerced into an inferior option. Substituting a behavioural nudging standard for the current coercion standard risks crossing the line to questioning whether consumer have the 'right preferences' to paternalism that is alien to competition law.

It is true that there is no bright line between mere nudging and coercion. If a behavioural consumer reaction to a given nudge is sufficiently automatic empirically, the 'nudge' may de facto amount to coercion. However, there must be very good evidence to show that informed consumer choice is impossible in the circumstances. Intervening without such evidence would result in antitrust enforcers overruling consumer preferences instead of protecting them against restraints.

Overall, I have serious doubts whether the allegations in the Commission's Statement of Objection constitute a competition law infringement. The 
Commission could arguably have prevailed on a backward-looking art 101 of the TFEU case regarding exclusivity clauses. ${ }^{168}$ It voluntarily took on a more difficult task by confining itself to art 102 of the TFEU and the self-preferencing theory of harm. The Commission then went further and reduced the inquiry to Google Shopping, where Amazon and eBay are particularly formidable competitors. ${ }^{169}$ I admire the Commission's willingness to take on the most difficult challenge first; perhaps this is to be expected from a Commissioner who likes Die Hard movies and 'always look[s] forward to when John McClane says Yippee ki-yay'. ${ }^{170}$

Only time will tell whether the Commission has the empirical evidence to back up its assertion that Google is dominant and has abused its position, or whether it is simply blinded by the ' 90 per cent search share' mantra and succumbing to the temptation to extrapolate Google's liability from the Microsoft case. This latter analogy overlooks that in Microsoft, both the dominant position (consolidated by the application barrier to entry) and the abuse (technological tying) were much clearer than in Google, where any barriers to entry in the form of alleged economies of scale are much more elusive, and the alleged abuse, consisting in mere nudging consumers to different search results, would break new ground by second-guessing the 'correct' consumer preferences. Let us hope the desire to utter the words 'Yippee ki-yay' does not transform into a 'shoot first, ask questions later' approach.

168 As Lianos and Motchenkova point out, these clauses prevented advertisers' multi-homing and, therefore, growth opportunities for Google's horizontal web search competitors: Lianos and Motchenkova, above n 76, 423, 428-33. But see Manne and Wright, above n 76, 229-38. Manne and Wright applied US law on exclusive dealing to Google's exclusive syndication agreements and found sufficient 'competition for the contract', no substantial foreclosure due to relatively short contract periods and substantial efficiencies: at 230.

169 Cf Lianos and Motchenkova, above n 76, 423 n 15. The authors note that Google's dominance in the product search segment is doubtful because of Amazon's presence. Again, the competitive constraint these actors put on Google in the product search segment does not depend on whether they are included in the relevant market or not. For the contention by some that Amazon and eBay should not be included, see above n 150 and accompanying text.

170 Alfonso Lamadrid, Interview with Margrethe Vestager (Online Interview, 30 January 2015) $<$ http://perma.cc/P2LT-PGM8>. 